\title{
Nitrogen and oxygen isotopic constraints on the origin of atmospheric nitrate in coastal Antarctica
}

\author{
J. Savarino ${ }^{1}$, J. Kaiser ${ }^{2,}$, S. Morin ${ }^{1}$, D. M. Sigman ${ }^{2}$, and M. H. Thiemens ${ }^{3}$ \\ ${ }^{1}$ Laboratoire de Glaciologie et Géophysique de l'Environnement, CNRS, Université Joseph Fourier-Grenoble, 54 rue Molière \\ BP96, St Martin d'Hères, 38402 France \\ ${ }^{2}$ Princeton University, Department of Geosciences, Princeton, NJ 08544, USA \\ ${ }^{3}$ University of California at San Diego, Department of Chemistry and Biochemistry, 9500 Gilman Drive, La Jolla, CA \\ 92093-0356, USA \\ * now at: University of East Anglia, School of Environmental Sciences, Norwich, Norfolk, NR4 7TJ, UK
}

Received: 25 July 2006 - Published in Atmos. Chem. Phys. Discuss.: 21 September 2006

Revised: 8 January 2007 - Accepted: 5 April 2007 - Published: 18 April 2007

\begin{abstract}
Throughout the year 2001, aerosol samples were collected continuously for 10 to 15 days at the French Antarctic Station Dumont d'Urville (DDU) $\left(66^{\circ} 40^{\prime} \mathrm{S}, 140^{\circ} 01^{\prime} \mathrm{E}, 40 \mathrm{~m}\right.$ above mean sea level). The nitrogen and oxygen isotopic ratios of particulate nitrate at DDU exhibit seasonal variations that are among the most extreme observed for nitrate on Earth. In association with concentration measurements, the isotope ratios delineate four distinct periods, broadly consistent with previous studies on Antarctic coastal areas. During austral autumn and early winter (March to mid-July), nitrate concentrations attain a minimum between 10 and $30 \mathrm{ng} \mathrm{m}^{-3}$ (referred to as Period 2). Two local maxima in August $\left(55 \mathrm{ng} \mathrm{m}^{-3}\right)$ and November/December $\left(165 \mathrm{ng} \mathrm{m}^{-3}\right)$ are used to assign Period 3 (mid-July to September) and Period 4 (October to December). Period 1 (January to March) is a transition period between the maximum concentration of Period 4 and the background concentration of Period 2. These seasonal changes are reflected in changes of the nitrogen and oxygen isotope ratios. During Period 2, which is characterized by background concentrations, the isotope ratios are in the range of previous measurements at midlatitudes: $\quad \delta^{18} \mathrm{O}_{\mathrm{vsmow}}=(77.2 \pm 8.6) \% \circ ; \quad \Delta^{17} \mathrm{O}=(29.8 \pm 4.4) \%$; $\delta^{15} \mathrm{~N}_{\text {air }}=(-4.4 \pm 5.4) \%$ (mean \pm one standard deviation $)$. Period 3 is accompanied by a significant increase of the oxygen isotope ratios and a small increase of the nitrogen isotope ratio to $\delta^{18} \mathrm{O}_{\text {vsmow }}=(98.8 \pm 13.9) \%$; $\Delta^{17} \mathrm{O}=(38.8 \pm 4.7) \%$ and $\delta^{15} \mathrm{~N}_{\text {air }}=(4.3 \pm 8.20 \%$ ). Period 4 is characterized by a minimum ${ }^{15} \mathrm{~N} /{ }^{14} \mathrm{~N}$ ratio, only matched by one prior study of Antarctic aerosols, and oxygen isotope ratios similar to Period 2: $\quad \delta^{18} \mathrm{O}_{\mathrm{vsmow}}=(77.2 \pm 7.7) \% ; \Delta^{17} \mathrm{O}=(31.1 \pm 3.2) \%$;
\end{abstract}

Correspondence to: J. Savarino

(savarino@lgge.obs.ujf-grenoble.fr) $\delta^{15} \mathrm{~N}_{\text {air }}=(-32.7 \pm 8.4) \%$ o. Finally, during Period 1, isotope ratios reach minimum values for oxygen and intermediate values for nitrogen: $\delta^{18} \mathrm{O}_{\mathrm{vsmow}}=63.2 \pm 2.5 \%$; $\Delta^{17} \mathrm{O}=24.0 \pm 1.1 \%$; $\delta^{15} \mathrm{~N}_{\text {air }}=-17.9 \pm 4.0 \%$ ). Based on the measured isotopic composition, known atmospheric transport patterns and the current understanding of kinetics and isotope effects of relevant atmospheric chemical processes, we suggest that elevated tropospheric nitrate levels during Period 3 are most likely the result of nitrate sedimentation from polar stratospheric clouds (PSCs), whereas elevated nitrate levels during Period 4 are likely to result from snow re-emission of nitrogen oxide species. We are unable to attribute the source of the nitrate during periods 1 and 2 to local production or long-range transport, but note that the oxygen isotopic composition is in agreement with day and night time nitrate chemistry driven by the diurnal solar cycle. A precise quantification is difficult, due to our insufficient knowledge of isotope fractionation during the reactions leading to nitrate formation, among other reasons.

\section{Introduction}

Inorganic particulate nitrate $\left(\mathrm{p}-\mathrm{NO}_{3}^{-}\right)$and nitric acid $\left(\mathrm{HNO}_{3}\right)$ are ubiquitous in the atmosphere. Because of their high solubility and chemical stability, wet and dry depositions are the ultimate sinks of these species. Being the end-product of the oxidation of atmospheric nitrogen oxides $\left(\mathrm{NO}_{\mathrm{x}}=\mathrm{NO}+\mathrm{NO}_{2}\right)$, nitrate is formed via (1) hydroxyl radical $(\mathrm{OH})$ oxidation of $\mathrm{NO}_{2}$, (2) $\mathrm{NO}_{2}$ oxidation to $\mathrm{N}_{2} \mathrm{O}_{5}$ followed by hydrolysis on particles and/or (3) $\mathrm{NO}_{2}$ oxidation to $\mathrm{NO}_{3}$ followed by $\mathrm{H}$ abstraction from reduced species (Finlayson-Pitts and Pitts,

Published by Copernicus GmbH on behalf of the European Geosciences Union. 
2000), and/or from (4) $\mathrm{BrONO}_{2} / \mathrm{ClONO}_{2}$ hydrolysis (von Glasow et al., 2004).

Nitrogen oxides act as important catalysts, modulating the oxidative capacity of the atmosphere by their effect on ozone levels. At the global scale, $\mathrm{NO}_{\mathrm{x}}$ sources are wellknown, although a precise quantification is difficult (Warneck, 2000). Lightning, fossil fuel combustion, soil exhalation, biomass burning and ammonia oxidation are the major tropospheric sources. $\mathrm{N}_{2} \mathrm{O}$ oxidation and $\mathrm{N}_{2}$ photodissociation and photo-ionization constitute the upper atmospheric sources (Brasseur and Solomon, 1986).

Despite decades of intense research, the source partitioning of nitrate in polar regions remains unclear (Wolff, 1995). The recent nitrate concentration increase observed in Greenland ice cores is attributed to industrial $\mathrm{NO}_{\mathrm{x}}$ emissions in the Northern Hemisphere (Mayewski et al., 1990). Such an increase has not been observed in Antarctica, suggesting that nitrate in this region of the world is still dominated by natural influences (Wolff, 1995). The low ratio of peroxyacetylnitrate $\left(\mathrm{PAN}, \mathrm{CH}_{3} \mathrm{C}(\mathrm{O}) \mathrm{OONO}_{2}\right)$ to $\mathrm{NO}_{\mathrm{x}}$ and the low PAN concentration at Antarctic costal sites argue for a weak influence of continental sources (Jacobi et al., 2000). At Neumayer, in February, Weller et al. (2002) demonstrated that methyl nitrate $\left(\mathrm{CH}_{3} \mathrm{ONO}_{2}\right)$ and PAN, in a ratio of roughly $1: 1$, are the two most abundant oxidized nitrogen $\left(\mathrm{NO}_{\mathrm{y}}\right)$ species in the Antarctic troposphere, accounting for ca. $68 \%$ of the $\mathrm{NO}_{\mathrm{y}}$ budget $\left(58 \mathrm{pmol} \mathrm{mol}^{-1}\right.$, with a possible oceanic source for alkyl nitrate species (Jones et al., 1999)). Weller et al. (2002) also recognized the predominance of organic nitrate $\left(\mathrm{PAN}+\right.$ alkyl nitrate $\approx 40 \mathrm{pmol} \mathrm{mol}^{-1}$ ) over inorganic nitrate $\left(\mathrm{HNO}_{3}+\mathrm{p}-\mathrm{NO}_{3}^{-} \approx 12 \mathrm{pmol} \mathrm{mol}^{-1}\right)$.

Zeller and co-workers (McCracken et al., 2001; Zeller and Parker, 1981) have proposed Solar Proton Events (SPEs) as a possible source of nitrate above Antarctica. However, this suggestion remains controversial (Herron, 1982; Legrand and Delmas, 1986; Jackman et al., 1990; Legrand and Kirchner, 1990; Palmer et al., 2001) and in any case, SPE should have only a discrete, time-limited impact on the nitrate budget. As a result, stratospheric $\mathrm{N}_{2} \mathrm{O}$ destruction and unspecified tropospheric sources for background $\mathrm{NO}_{\mathrm{x}}$ (presumably biomass burning, lightning, and/or ocean) are believed to be the only significant sources of Antarctic nitrate (Wolff, 1995; Wagenbach et al., 1998). It should be borne in mind that none of the degradation products of organic nitrates are expected to form inorganic nitrate directly (Shallcross et al., 1997; Finlayson-Pitts and Pitts, 2000), but they are most probably a direct source of $\mathrm{NO}_{\mathrm{x}}$.

The quantification of nitrate sources in polar regions is complicated by the fact that nitrate is not irreversibly trapped in snow. Neubauer and Heumann (1988) were the first to recognize that nitrate in surface snow undergoes postdepositional processes, confirmed later by a number of other studies and attributed to photolysis and/or evaporation (Dibb and Whitlow, 1996; Mulvaney et al., 1998; Wagnon et al., 1999; Röthlisberger et al., 2002; Udisti et al., 2004). Beyond its effect on the preservation of nitrate in snow, nitrate photolysis, first documented by Honrath et al. (1999), is now recognized as an important regional source of $\mathrm{NO}_{\mathrm{x}}$ and $\mathrm{HONO}$ (Jones et al., 2000; Domine and Shepson, 2002; Beine et al., 2002; Davis et al., 2004a), with a possible enhancement in emissions since the appearance of the stratospheric ozone "hole" (Jones and Wolff, 2003). Although the South Pole boundary layer is the most pristine on Earth (see for instance ISCAT special issue (Davis et al., 2004a)), these emissions make it as oxidative as urban atmospheres (Monks, 2005). An intense research effort is currently devoted to understand and quantify such emissions, including the post-depositional effects leading to remobilization of nitrate in snow (Dibb and Whitlow, 1996; Mulvaney et al., 1998; Honrath et al., 2000b, 2002; Nakamura et al., 2000; Jones et al., 2000; Röthlisberger et al., 2000, 2002; Beine et al., 2002; Wolff et al., 2002; Cotter et al., 2003; Burkhart et al., 2004; Blunier et al., 2005).

With the recent advances of online mass spectrometry techniques (Brand, 1996) coupled with high sensitivity nitrate analysis (Sigman et al., 2001; Casciotti et al., 2002; Kaiser et al., 2007), the stable isotope composition of polar nitrate has emerged as a new tool of investigation, complementing concentration measurements. Because the nitrogen atom is conserved between $\mathrm{NO}_{\mathrm{x}}$ sources and nitrate sinks, the nitrogen isotope composition is generally viewed as fingerprint of $\mathrm{NO}_{\mathrm{x}}$ sources (Moore, 1977; Freyer, 1978, 1991; Heaton, 1990; Hastings et al., 2004), whereas the oxygen isotope composition is related to $\mathrm{NO}_{\mathrm{x}}$ oxidation pathways (Michalski et al., 2003; Hastings et al., 2003, 2005; Morin et al., 2007).

In an effort to resolve the origin and fate of nitrate in Antarctica, we report here on a year-long isotopic survey of nitrate aerosols collected at Dumont d'Urville. This study represents the first comprehensive picture of nitrate isotopes that combines the three isotopic ratios ${ }^{15} \mathrm{~N} /{ }^{14} \mathrm{~N},{ }^{17} \mathrm{O} /{ }^{16} \mathrm{O}$ and ${ }^{18} \mathrm{O} /{ }^{16} \mathrm{O}$. The nitrogen and oxygen isotopes are used to probe potential sources of nitrate in Antarctica. The core of this study is dedicated to understanding the seasonal cycle of particulate nitrate $\left(\mathrm{p}-\mathrm{NO}_{3}^{-}\right)$concentrations at coastal Antarctic stations.

\section{Sampling site and experimental procedure}

\subsection{Sampling site}

A detailed description of the sampling location can be found in Wolff et al. (1998). We provide here the principal characteristics. Dumont d'Urville (DDU) $\left(66^{\circ} 40^{\prime} \mathrm{S}, 140^{\circ} 01^{\prime} \mathrm{E}\right)$ is located on a small island (Ile des Pétrels, $0.45 \mathrm{~km}^{2}$ ), $1 \mathrm{~km}$ North of the Antarctic mainland. The site is located in the Pacific sector of Antarctica, facing Australia. During summer, the island is partly snow-free with gneiss rock outcrops. Such 
rocks produce little mineral aerosols in the sub-micrometer size range.

Some 12000 Adélie penguins nest on this inland during the summer, from the end of October to late February. A large population of Adélie penguins is also present on islands around DDU, with a total population estimated at 60000 individuals. In addition, some 7000 Emperor penguins sit through the winter at this site. Technical and scientific staff numbers fluctuate between about 60 in the summer and about 20 in the winter.

The meteorological climatology at DDU is described in detail by König-Langlo et al. (1998). In summer, DDU is surrounded by open ocean water. The average surface air temperatures range from $-1{ }^{\circ} \mathrm{C}$ in January to $-17^{\circ} \mathrm{C}$ in winter, with a mean annual temperature of $-11^{\circ} \mathrm{C}$. The annual mean surface wind speed is $9.5 \mathrm{~m} \mathrm{~s}^{-1}$, with no clear seasonal variations. Strong katabatic winds dominate at DDU, favoring the $120-160^{\circ}$ wind sector. Southerly air mass advection from the Antarctic interior occurs up to $2 \mathrm{~km}$ altitude throughout the year, isolating the marine boundary layer from lower latitude air masses above it. The tropopause is located between 9 and $11 \mathrm{~km}$ altitude, slightly higher from September to October. DDU is at the edge of the polar vortex and strong zonal winds $\left(>50 \mathrm{~m} \mathrm{~s}^{-1}\right.$ ) prevail above $10 \mathrm{~km}$ from late autumn to end of winter.

\subsection{Sample collections and controls}

A Thermo Andersen (formerly Graseby-Andersen) highvolume air sampler (HVAS; model GL 2000H) equipped with a four-stage cascade impactor and a backup glass fiber filter was used to collect size-segregated atmospheric particles. The cascade impactor was mounted with four slotted $12.7 \mathrm{~cm} \times 17.8 \mathrm{~cm}$ glass fiber filters in series with an additional $20.3 \mathrm{~cm} \times 25.4 \mathrm{~cm}$ backup fiber glass filter to collect the smallest particles.

The HVAS was situated on a platform, $1 \mathrm{~m}$ above ground, $50 \mathrm{~m}$ away from the shore and $20 \mathrm{~m}$ away from the closest building (Labo 3). It was usually operated at 1.3 to 1.5 cubic meter per minute (calibrated prior to deployment) for 10 to 15 successive days (20000 to $30000 \mathrm{~m}^{3} / \mathrm{sample}$ ) to ensure sufficient amount of aerosols (nitrate, sulfate) for isotopic analysis.

Atmospheric nitrate concentrations were calculated from the aerosol filter loading and the air volume pumped through the filter (corrected to standard temperature and pressure, STP, $T=273.15 \mathrm{~K}, p=101325 \mathrm{~Pa}$ ) assuming a constant flow rate throughout the year. For most samples, the field operators did not record the end date of sampling, in which case we assume that the collection was running until the start date of the following sample. The concentration data obtained from the HVAS could therefore be by up to a factor of two too low for isolated samples, but because the seasonal pattern of the atmospheric concentration varies by a factor of 16 , this potential error has a negligible impact on the interpretation of the seasonal variation and does not affect the calculation of the weighted average $\delta$ values.

There is no "clean sector" defined due to the small size of the island. During brief periods of waste incineration at the station, the HVAS was stopped by the operators. Wagenbach et al. (1998) have conducted an exhaustive survey of coastal Antarctic nitrate, including the DDU site. Comparison of concentration profiles at different locations in and around DDU led these authors to conclude that neither the station activities nor the dense penguin colonies were likely a source of nitrate contamination in the local atmosphere.

One blank control sample was collected at the start of the season. This blank was treated identically to the samples, i.e., the cascade impactor was loaded with regular filters, except that the HVAS was not turned on. Comparison of this blank with samples shows that the contamination it is at most $10 \%$ and $6 \%$ of the wintertime and summertime concentration respectively, with $4 \%$ on average. The isotopic composition of the blank was measured as follow: $\delta^{18} \mathrm{O}_{\mathrm{vsmow}}=65.7 \%$; $\Delta{ }^{17} \mathrm{O}=21.2 \%$; $\delta^{15} \mathrm{~N}_{\text {air }}=-1.0 \%$. For each filter sample, this blank was subtracted using an isotopic mass balance, based on the blank concentration and its isotopic composition.

DDU is known to be a place with high atmospheric ammonia and sea-salt concentrations (Legrand et al., 1998; Wagenbach et al., 1998; Jourdain and Legrand, 2002), leading to an alkaline bulk aerosol year-round. Recent measurements (Jourdain and Legrand, 2002) using denuder techniques revealed that partitioning between gaseous $\mathrm{HNO}_{3}$ and particulate nitrate is close to $1: 1$. Such a high gaseous fraction may interfere with the alkaline bulk aerosols deposited on the filter, generating erroneously high $\mathrm{p}-\mathrm{NO}_{3}^{-}$measurements. Until direct isotopic measurement is performed on gaseous $\mathrm{HNO}_{3}$, the impact of such a compound on the isotopic composition of the bulk nitrate collected on filter media will remain unknown. This remark is also valid for other oxidized nitrogen compounds such as $\mathrm{NO}_{\mathrm{x}}$, PAN and organic nitrates which have the potential to interfere with the sampled aerosol. At this stage no evaluation can be made on such interferences, and the atmospheric community is restricted to the interpretation of what it is recovered on the filters (Wagenbach et al., 1998; Schaap et al., 2002), keeping in mind that other oxidized nitrogen compounds may have also been trapped.

\subsection{Nitrate extraction and analysis}

All glass fiber filters were pre-cleaned by an overnight soak and several rinses with ultra pure water (Millipore, $18 \mathrm{M} \Omega \mathrm{cm}$ ), dried in a class 10000 clean room and finally stored in clean plastic food storage bags (Ziploc) before being shipped to Antarctica. After each collection period, filters were removed from the cascade impactor in a clean hood and stored in clean $50 \mathrm{ml}$-centrifuge tubes at $-20^{\circ} \mathrm{C}$. Samples were transported frozen back to our laboratory in Grenoble for extraction of soluble species. 
Before sample extraction in Grenoble, the filters were inspected visually. In two cases, penguin feathers or bird faeces were found on the first stage of the impactor. These filters were discarded. However, only marginal nitrate mass loss is expected from the coarse aerosol mode collected on this filter stage (Jourdain and Legrand, 2002). The four slotted filters (SF) were grouped together while the backup filter (BU) was treated individually. In this manner, filters were processed according to the aerodynamic diameter of the aerosols collected with larger particles $(>1 \mu \mathrm{m}$ aerodynamic cutoff diameter, given by the impactor manufacturer) preferentially collected on SF filters. The primary purpose of the cascade impactor is to separate and analyze sea-salt and non sea-salt sulfate aerosols (to be analyzed in the future).

Filters were placed with $40 \mathrm{ml}$ of ultra-pure water in a centrifugal filter unit (Millipore Centricon plus-70) for $15 \mathrm{~min}$, shaken a few times and filtered at $3000 \mathrm{~g}$ in a centrifuge. Thus, more than $98 \%$ of the initial water volume can be recovered. Small quantities $(200 \mu \mathrm{l})$ of sample solution were taken and diluted 200 times for ion chromatography analysis. $\mathrm{NO}_{3}^{-}$concentrations were determined using the ionchromatography system described in Preunkert et al. (2001) and used to calculate atmospheric nitrate mass concentrations.

After quantification, a predetermined volume of sample was extracted ( 0.5 to $8 \mathrm{ml})$ to secure $200 \mathrm{nmol}$ of nitrate for isotopic analysis and shipped frozen to Princeton University. The remainder of the sample was kept frozen and archived for future analysis.

${ }^{15} \mathrm{~N} /{ }^{14} \mathrm{~N}$ and ${ }^{18} \mathrm{O} /{ }^{16} \mathrm{O}$ isotope ratio analyses were performed by conversion of nitrate to $\mathrm{N}_{2} \mathrm{O}$ using the denitrifier method and direct isotope analysis of the $\mathrm{N}_{2} \mathrm{O}$ (Sigman et al., 2001; Casciotti et al., 2002). The triple oxygen isotopic composition $\left({ }^{17} \mathrm{O} /{ }^{16} \mathrm{O},{ }^{18} \mathrm{O} /{ }^{16} \mathrm{O}\right)$ was measured with a novel method based on on-line conversion of $\mathrm{N}_{2} \mathrm{O}$ (from the denitrifer method) to $\mathrm{O}_{2}$ using a gold tube held at $800^{\circ} \mathrm{C}$ in a tube furnace (Kaiser et al., 2007). For the denitrifier method alone, we used a nominal nitrate amount of $20 \mathrm{nmol}$ nitrate, whereas the $\mathrm{N}_{2} \mathrm{O}$ decomposition method required $50 \mathrm{nmol}$ nitrate to ensure good reproducibility.

Despite significant differences, the analysis of $\mathrm{BU}$ and SF samples show a similar seasonal cycle for all isotopic ratios (Fig. S1 and Table S1 in supplemental materials: http://www.atmos-chem-phys.net/7/1925/2007/ acp-7-1925-2007-supplement.zip). As we are mostly interested in the variations throughout the year, it is therefore justified to merge both datasets into one, weighting the isotopic composition of the BU and SF filters by the corresponding filter loadings. Further analysis of other collections archived in our laboratory will be used at a later stage to investigate the differences between the isotopic composition of nitrate retained by the BU and SF filters, respectively.

\subsection{Isotopic scales and definitions}

Isotopic compositions are reported as delta values relative to an international reference material:

$\delta=\frac{R_{\text {spl }}}{R_{\text {ref }}}-1$

where $R_{s p l}$ is the elemental isotope ratio of the sample and $R_{\text {ref }}$ the elemental isotope ratio of the reference material. In the case of nitrate, $R$ can refer to either ${ }^{15} \mathrm{~N} /{ }^{14} \mathrm{~N},{ }^{17} \mathrm{O} /{ }^{16} \mathrm{O}$ or ${ }^{18} \mathrm{O} /{ }^{16} \mathrm{O}$. Atmospheric nitrogen $\left(\mathrm{N}_{2}\right)$ has been established as the international reference for ${ }^{15} \mathrm{~N} /{ }^{14} \mathrm{~N}$ ratios (Mariotti, 1983, 1984). For oxygen isotopes, Vienna Standard Mean Ocean Water (VSMOW) is the international reference material.

The oxygen isotopic system offers three stable isotopes, allowing a comparison of their respective behavior. Most kinetic and equilibrium processes, such as isotopic exchange or diffusion, fractionate isotopes according to their relative mass differences and form linear arrays in a three-isotope plot of $\ln \left(1+\delta^{17} \mathrm{O}\right)$ versus $\ln \left(1+\delta^{18} \mathrm{O}\right)$ with a slope between 0.5 and 0.531 (Young et al., 2002). This is called a massdependent isotope effect (Bigeleisen, 1952; Matsuhisa et al., 1978). Thiemens and Heidenreich III (1983) discovered that ozone formation does not follow a mass-dependent relationship and that ${ }^{17} \mathrm{O}$ had an anomalous enrichment in comparison to ${ }^{18} \mathrm{O}$. Explaining the cause of the ${ }^{17} \mathrm{O}$ isotope anomaly in ozone remains a major challenge in physical chemistry (Gao and Marcus, 2001; Brenninkmeijer et al., 2003) and is beyond the scope of this paper. Since ozone is a strong oxidant and found nearly everywhere in the atmosphere, many other atmospheric species, including nitrate (Michalski et al., 2003), have been shown to possess anomalous ${ }^{17} \mathrm{O} /{ }^{16} \mathrm{O}$ ratios, inherited from $\mathrm{O}_{3}$ (Thiemens et al., 2001).

Several expressions have been proposed for quantifying the ${ }^{17} \mathrm{O}$ isotope anomaly $\left(\Delta^{17} \mathrm{O}\right)$ (Thiemens, 1999; Farquhar et al., 2000; Miller, 2002; Kaiser et al., 2004). In the present study, we use the linear definition with a mass-dependent coefficient of 0.52:

$$
\Delta^{17} \mathrm{O}=\delta^{17} \mathrm{O}-0.52 \delta^{18} \mathrm{O}
$$

The motivation of this choice are firstly, to be consistent with previous published works on the same topic (Michalski et al., 2003; Alexander et al., 2004; McCabe et al., 2005a; Morin et al., 2007) and secondly, to allow easy mass balance calculation based on $\Delta^{17} \mathrm{O}$ measurements. The most suitable value of the coefficient depends on the process under consideration, since different kinetic and equilibrium isotope fractionation processes are characterized by different relationships between $\ln \left(1+\delta^{17} \mathrm{O}\right)$ and $\ln \left(1+\delta^{18} \mathrm{O}\right.$ ) (for instance, Miller, 2002; Young et al., 2002; Angert et al., 2003; Assonov and Brenninkmeijer, 2005). There is no single atmospheric process that could be held responsible for producing mass dependently fractionated nitrate and it is therefore not possible to establish a single most suitable coefficient for nitrate. We 
Table 1. Sampling and analytical methodologies for the aerosol collections used for the high-volume and low volume aerosol collector.

\begin{tabular}{|c|c|c|}
\hline & Low-Vol & Hi-Vol \\
\hline Collection interval & $1-3$ days & $10-15$ days \\
\hline Location & $\begin{array}{l}\text { At the rear of building "Labo 3", } 1.8 \mathrm{~m} \text { above } \\
\text { ground }\end{array}$ & $\begin{array}{l}20 \mathrm{~m} \text { away from building "Labo 3", } 1 \mathrm{~m} \text { above } \\
\text { ground }\end{array}$ \\
\hline Filter media & $\emptyset 47 \mathrm{~mm}, 0.4 \mu \mathrm{m}$ PTFE & $\begin{array}{l}20.3 \mathrm{~cm} \times 25.4 \mathrm{~cm} \text { glass filter, mounted with four } \\
\text { slotted } 12.7 \mathrm{~cm} \times 17.8 \mathrm{~cm} \text { glass filter in series (im- } \\
\text { pactor stages) }\end{array}$ \\
\hline Pump flow & $0.01 \mathrm{~m}^{3} \mathrm{~min}^{-1}$ & Typically $1.2 \mathrm{~m}^{3} \mathrm{~min}^{-1}$ \\
\hline
\end{tabular}

therefore use the value of 0.52 , which represents a good average of mass-dependent coefficients expected and observed in nature (Matsuhisa et al., 1978; Barkan and Luz, 2003; Kaiser et al., 2004; Weston, 2006).

Analytical uncertainty (1 standard deviation) is estimated based on replicate measurements of a subset of samples and amounts to $0.2 \%$ ofor $\delta^{15} \mathrm{~N}, 0.5 \%$ ofor $\delta^{18} \mathrm{O}$ (denitrifier method (Casciotti et al., 2002)), $0.9 \%$ for $\delta^{18} \mathrm{O}$ and $0.5 \%$ for $\Delta^{17} \mathrm{O}\left(\mathrm{N}_{2} \mathrm{O}\right.$ decomposition method, Kaiser et al., 2007).

\section{Results}

We present data from 27 collection periods at DDU, covering the period from 6 January 2001 to 22 December 2001. In parallel to our collection, an aerosol monitoring program (AMP) has been in operation since 1991, measuring the ionic composition of the aerosol continuously with year-round daily observations. Measurements of meteorological data, lidar aerosol and ozone concentrations, solar flux at ground level and vertical profiles of temperature, ozone, solar flux, wind direction and wind speed are performed regularly. These datasets were used whenever appropriate.

\subsection{Atmospheric concentration of inorganic nitrate aerosols}

Figure 1a shows a comparison between the HVAS nitrate concentration time series and the one obtained by the AMP (M. Legrand and S. Preunkert, personal communication, 2006) for the year 2001. Data of the AMP have been averaged over each HVAS collection period in order to facilitate the comparison. Overall, both time series agree well despite very different sampling conditions (Table 1). A comparison with other published seasonally-resolved concentrations (Wagenbach et al., 1998) shows no major discrepancies of the main temporal features even if this latter study depicts maximum concentration measurements $\left(\left[\mathrm{NO}_{3}^{-}\right]=(41 \pm 11) \mathrm{ng} \mathrm{m}^{-3}\right)$ lower than the more recent observations $\left(\left[\mathrm{NO}_{3}^{-}\right]=(116.4 \pm 41.1) \mathrm{ng} \mathrm{m}^{-3}\right)$. Atmospheric concentrations of particulate nitrate show a strong seasonal cycle: From January to March (period 1), concentrations de- crease steadily and reach a background concentration level of $\approx 12 \mathrm{ng} \mathrm{m}^{-3}$ during March to mid July (period 2). From mid July to September (period 3), concentrations increase to a peak of $\approx 55 \mathrm{ng} \mathrm{m}^{-3}$. This moderate concentration increase at this time of the year is a significant and general observation observed around Antarctica (Wagenbach et al., 1998). Finally, October to December (period 4) is characterized by the occurrence of a major concentration peak, with concentrations reaching $\approx 165 \mathrm{ng} \mathrm{m}^{-3}$. The observed seasonal pattern of $\mathrm{p}-\mathrm{NO}_{3}^{-}$concentration in 2001 at DDU is in line with any other year analyzed so far (Wagenbach et al., 1998; Rankin and Wolff, 2003).

\subsection{Isotopic measurements}

Table 2 and Fig. 1 provide the measured values of the nitrate concentrations, $\delta^{15} \mathrm{~N}, \delta^{18} \mathrm{O}$ and $\Delta^{17} \mathrm{O}$. As a general observation, the isotopic ratios show strong seasonal patterns, in line with the concentrations and represent the most extreme values ever reported for nitrate.

Nitrate aerosol $\delta^{15} \mathrm{~N}$ values range from -46.9 to $+10.8 \%$, with its minimum in November. This seasonal pattern is identical to the one previously reported by Wagenbach et al. (1998) at Neumayer (Fig. 1b). To the best of our knowledge, the low $\delta^{15} \mathrm{~N}$ nitrate values observed during the late spring concentration peak have only been documented in Antarctic environments (i.e. soil, snow, air) (Wada et al., 1981; Wagenbach et al., 1998; Michalski et al., 2005).

Our $\delta^{18} \mathrm{O}$ measurements also show an extended range of values, spanning from about 60 to $111 \%$ with relatively good agreement between the two analytical methods (direct $\mathrm{N}_{2} \mathrm{O}$ (Casciotti et al., 2002) and catalytic decomposition of $\mathrm{N}_{2} \mathrm{O}$ on gold (Kaiser et al., 2007)) used in the present study (Fig. 1c and Table S1 at http://www.atmos-chem-phys.net/ 7/1925/2007/acp-7-1925-2007-supplement.zip). The average $\delta^{18} \mathrm{O}$ value measured by the decomposition method is $(1.7 \pm 3.4) \%$ higher than the direct $\mathrm{N}_{2} \mathrm{O}$ measurement. This is more than expected based on the measurement uncertainty and the cause cannot be explained quantitatively at the moment (Kaiser et al., 2006), but the conclusions drawn here are not altered in any way by the choice of the $\delta^{18} \mathrm{O}$ measure- 
Table 2. Weighted average of the two size ranges for $\delta^{15} \mathrm{~N}, \delta^{18} \mathrm{O}, \Delta{ }^{17} \mathrm{O}$, and atmospheric nitrate concentration recorded at Dumont d'Urville in 2001. $\delta^{18} \mathrm{O}$ values are those obtained by the $\mathrm{N}_{2} \mathrm{O}$ decomposition method (Kaiser et al., 2007). Standard deviations are $0.2,0.9$ and $0.5 \%$ o for $\delta^{15} \mathrm{~N}, \delta^{18} \mathrm{O}, \Delta^{17} \mathrm{O}$, respectively (see text for details).

\begin{tabular}{|c|c|c|c|c|}
\hline Dates $^{\mathrm{a}}$ & $\begin{array}{l}\text { Atmospheric concentration, } \\
\text { corrected to STP }\left(\mathrm{ng} \mathrm{m}^{-3}\right)\end{array}$ & $\delta^{15} \mathrm{~N}_{\text {air }}(\% o)$ & $\delta^{18} \mathrm{O}_{\text {VSMOW }}(\% \circ)$ & $\Delta^{17} \mathrm{O}^{\mathrm{b}}(\% o)$ \\
\hline 6 Jan 2001 & 43.1 & -20.4 & 63.1 & 25.0 \\
\hline 16 Jan 2001 & 13.8 & -18.4 & 62.9 & 23.0 \\
\hline 30 Jan 2001 & 27.5 & -22.3 & 63.9 & 24.7 \\
\hline 9 Feb 2001 & 22.1 & -11.9 & 59.6 & 22.5 \\
\hline 19 Feb 2001 & 17.5 & -16.6 & 66.6 & 24.7 \\
\hline 5 March 2001 & 10.3 & -11.4 & 60.9 & 20.0 \\
\hline 27 March 2001 & 11.1 & -6.7 & 77.6 & 28.5 \\
\hline 10 April 2001 & 17.4 & -11.4 & 84.7 & 31.7 \\
\hline 19 April 2001 & 11.1 & -7.6 & 85.2 & 32.8 \\
\hline 5 May 2001 & 15.7 & 0.5 & 86.0 & 33.3 \\
\hline 16 May 2001 & 10.5 & 0.0 & 74.9 & 30.1 \\
\hline 31 May 2001 & 9.2 & 0.5 & 70.6 & 28.7 \\
\hline 18 June 2001 & 12.3 & 0.7 & 77.4 & 32.9 \\
\hline 6 July 2001 & 22.4 & 5.0 & 70.0 & 29.3 \\
\hline 19 July 2001 & 14.2 & 9.9 & 103.1 & 41.1 \\
\hline 3 Aug 01 & 55.0 & 6.4 & 97.6 & 37.3 \\
\hline 7 Aug 2001 & 22.8 & 10.0 & 111.4 & 43.0 \\
\hline 22 Aug 2001 & 49.2 & 10.8 & 110.9 & 43.1 \\
\hline 12 Sep 2001 & 35.5 & -0.1 & 100.7 & 38.6 \\
\hline 27 Sep 2001 & 55.1 & -12.3 & 98.0 & 38.9 \\
\hline 9 Oct 2001 & 58.5 & -21.1 & 91.1 & 37.4 \\
\hline 23 Oct 2001 & 94.8 & -28.9 & 84.8 & 32.8 \\
\hline 2 Nov 2001 & 84.3 & -46.9 & 74.8 & 29.0 \\
\hline 16 Nov 2001 & 158.3 & -36.0 & 72.6 & 31.7 \\
\hline 28 Nov 2001 & 165.3 & -29.3 & 74.2 & 29.7 \\
\hline 14 Dec 2001 & 154.9 & -28.9 & 72.2 & 28.8 \\
\hline 22 Dec 2001 & 101.5 & -38.2 & 70.6 & 28.3 \\
\hline
\end{tabular}

a Starting date of collection

${ }^{\mathrm{b}}$ Calculated using Eq. (2) (see text)

ment technique. Like the low $\delta^{15} \mathrm{~N}$ values at the other end of the scale, this $\delta^{18} \mathrm{O}$ peak of $111 \%$ attained in August represents the most extreme ${ }^{18} \mathrm{O}$ enrichment ever reported for nitrate in natural environments (Kendall, 1998; Hastings et al., 2003, 2004, 2005; Michalski et al., 2003, 2004a, b, 2005; Heaton et al., 2004; Morin et al., 2007). Fewer studies exist on $\Delta{ }^{17} \mathrm{O}$ due to the difficulty of measuring the less abundant ${ }^{17} \mathrm{O}$ isotope. $\Delta^{17} \mathrm{O}$ values span from 20.0 to $43.1 \%$ and follow the $\delta^{18} \mathrm{O}$ profile (Table 2 and Fig. 1d). Again, this is the largest range ever observed (Michalski et al., 2003, 2004a, b, 2005; Alexander et al., 2004; Morin et al., 2007), only matched by recent measurements of atmospheric nitrate at South Pole (McCabe et al., 2005a). These graphs show that the four periods established from the concentration measurements are reflected by the isotope profiles. In Table 3, we give the principal characteristics for each period. Figure 2 summarizes the above presentation. In this figure, $\Delta{ }^{17} \mathrm{O}$ is plotted against $\delta^{15} \mathrm{~N}$ along with the nitrate atmospheric con- centration. The four periods established from the time-series are clearly visible. Each period bears its own concentration, nitrogen and oxygen isotopic characteristics in a seasonal cycle that follows a cyclical evolution in this plot.

There is a strong correlation between $\delta^{18} \mathrm{O}$ and $\Delta^{17} \mathrm{O}$ (Fig. 3). This is an indication that the oxygen isotopic composition of $\mathrm{NO}_{\mathrm{x}}$ and atmospheric nitrate is mostly controlled by oxygen atom transfers and little impacted by fractionation linked to specific chemical reactions : if fractionation processes (either mass-dependent or mass-independent, in a variety of proportions depending on the mechanisms) were to proceed significantly, this would affect $\delta^{18} \mathrm{O}$ and $\Delta^{17} \mathrm{O}$ values in different ways, thus not resulting in a correlation, as observed throughout the dataset. In the following, we disregard mass-dependent oxygen fractionation and concentrate only on isotopic transfer using the $\Delta{ }^{17} \mathrm{O}$ tracer. 


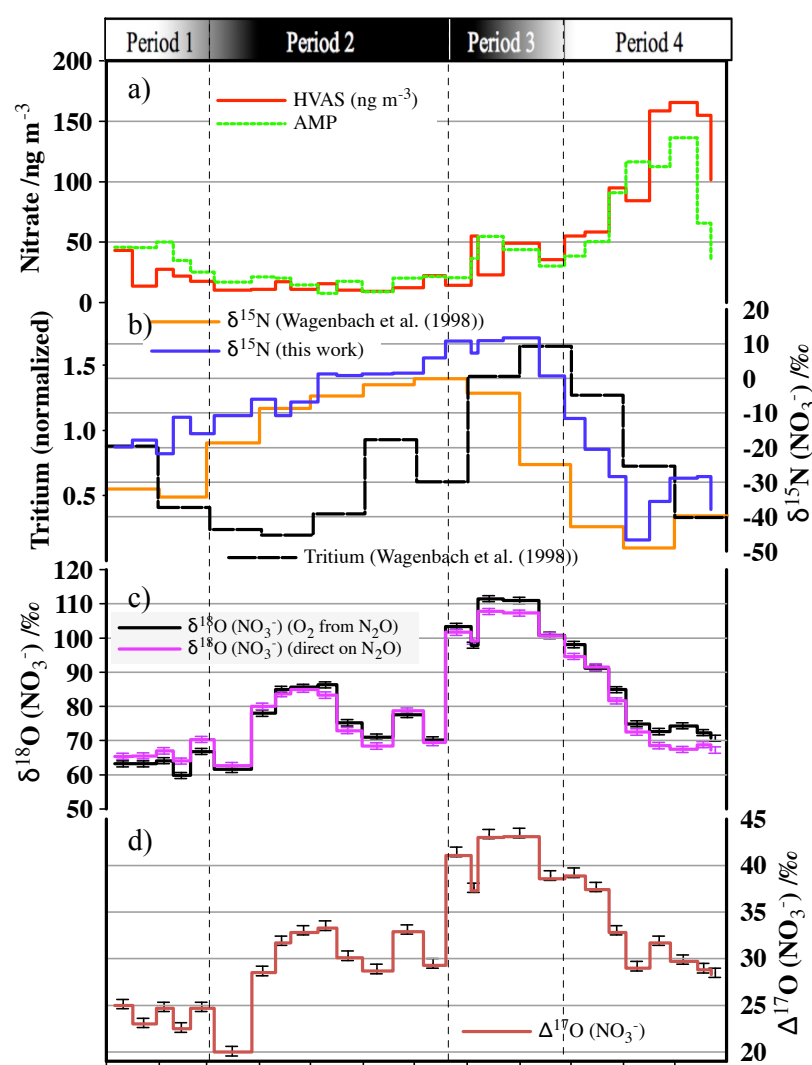

Jan FebMarAprMayJun Jul AugSep Oct NovDec Date in 2001

Fig. 1. From top to bottom: Top banner symbolizes polar night (black) and day (white) during the year. (a) Particulate nitrate concentrations as recorded by our HiVol aerosol sampler (red) and by the aerosol monitoring program (green). For the latter, the data have been averaged according to the same time window as the HVAS collection time. Concentrations exhibit a strong seasonal variation with a maximum observed in late spring (NovemberDecember). A significant secondary peak is observed in late winter (August-September). Shortly afterwards, tritium levels in precipitation (black, right axis) reach a maximum (Wagenbach et al., 1998). (b) $\delta^{15} \mathrm{~N}\left(\mathrm{NO}_{3}^{-}\right)$as observed by this study (blue) compared with the Wagenbach et al. (1998) study. Both ${ }^{15} \mathrm{~N}$ profiles are very similar and display strong negative $\delta^{15} \mathrm{~N}$ values in late spring. (c) Same as (b) but for $\delta^{18} \mathrm{O}$. We have used two techniques to measure $\delta^{18} \mathrm{O}\left(\mathrm{NO}_{3}^{-}\right)$. The former uses the thermal decomposition of $\mathrm{N}_{2} \mathrm{O}$ on gold (black line) and the analysis is performed on produced $\mathrm{O}_{2}$, the latter uses directly $\mathrm{N}_{2} \mathrm{O}$ as the working gas (pink line). Just as $\delta^{15} \mathrm{~N}\left(\mathrm{NO}_{3}^{-}\right), \delta^{18} \mathrm{O}\left(\mathrm{NO}_{3}^{-}\right)$values vary seasonally with their maximum observed in late winter (ca. $+110 \%$ ). A secondary peak is observed during polar sunset (April-May). (d) Same as (c) but for $\Delta^{17} \mathrm{O}\left(\mathrm{NO}_{3}^{-}\right) . \Delta^{17} \mathrm{O}$ values exhibit the same features as $\delta^{18} \mathrm{O}$ with a maximum value of ca. $+40 \%$ in late winter. This is highest oxygen isotope anomalies ever recorded for nitrate.

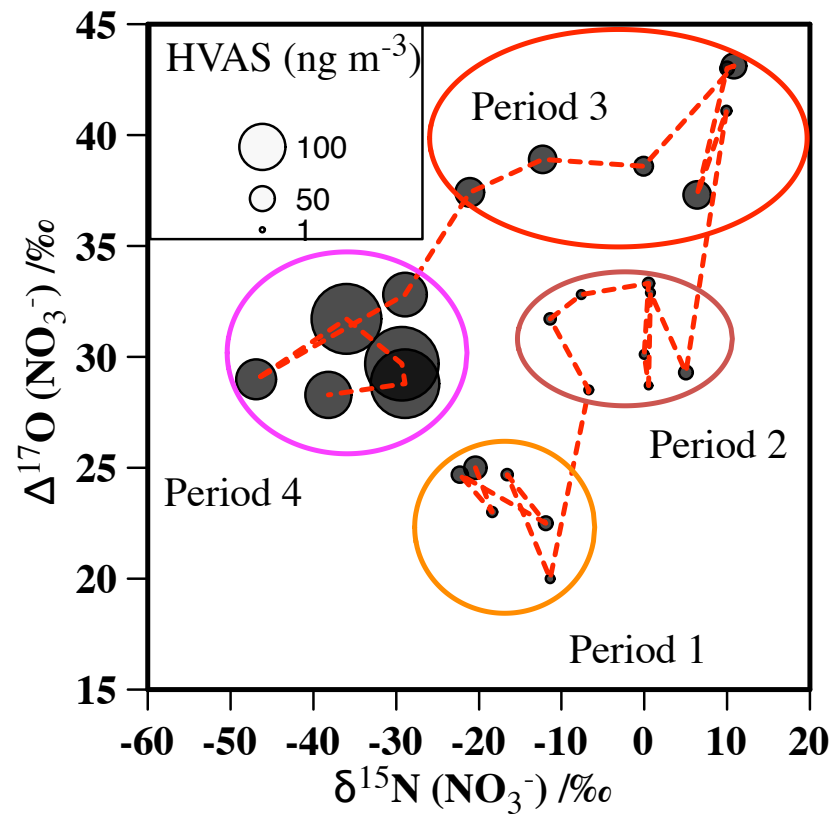

Fig. 2. Plot of $\Delta^{17} \mathrm{O}$ vs. $\delta^{15} \mathrm{~N}\left(\mathrm{NO}_{3}^{-}\right)$at DDU over the course of year 2001, showing the seasonal variations in both $\mathrm{N}$ and $\mathrm{O}$ isotopic compositions. The size of the circles corresponds to the atmospheric particulate nitrate concentrations. The four periods discriminated from the concentration time series are highlighted in terms of their isotopic characteristics and show that distinct isotopic signatures are associated with each of them, hence justifying this separation into separate periods. Periods 1 and 2 are best explained by tropospheric isotopic chemistry. Period 3 corresponds to stratospheric nitrate injection while period 4 is explained by inland snow re-emissions.

\section{Discussion}

\subsection{Sources of nitrate and mechanisms of formation}

Nitrate is not directly injected into the atmosphere. Atmospheric nitrate always results from the transformation of $\mathrm{NO}_{2}$ to gaseous nitric acid which eventually is neutralized by alkaline particles and incorporated into aerosols. Because $\mathrm{NO}_{2}$ is in photochemical equilibrium with $\mathrm{NO}$ and $\mathrm{O}_{3}$, deciphering the source of atmospheric nitrate reduces to the identification of $\mathrm{NO}_{\mathrm{x}}$ sources and the oxidation pathways ultimately leading to nitrate. Due to the remoteness of the Antarctic continent, three sources of nitrate are deemed most important: stratospheric input, continental background sources (e.g. biomass burning, lightning) (Wolff, 1995) and possibly the snowpack (Domine and Shepson, 2002).

\subsubsection{The stratospheric source}

In the lower stratosphere, nitric acid precursors are $\mathrm{NO}_{\mathrm{x}}$ produced by the reaction $\mathrm{N}_{2} \mathrm{O}+\mathrm{O}\left({ }^{1} \mathrm{D}\right)$ and $\mathrm{NO}_{\mathrm{x}}$ produced following $\mathrm{N}_{2}$ photo-ionization and photo-dissociation in the thermosphere, mesosphere and upper stratosphere (Brasseur 
Table 3. Concentration and isotope characteristics of the four periods comprising the seasonal cycles of inorganic nitrate particles at DDU.

\begin{tabular}{lllll}
\hline & $\begin{array}{l}\text { Period 1 } \\
\text { (January to March) }\end{array}$ & $\begin{array}{l}\text { Period 2 } \\
\text { (March to mid-July) }\end{array}$ & $\begin{array}{l}\text { Period 3 } \\
\text { (mid-July to September) }\end{array}$ & $\begin{array}{l}\text { Period 4 } \\
\text { (October to December) }\end{array}$ \\
\hline $\mathrm{NO}_{3}^{-}\left(\mathrm{ng} \mathrm{m}^{-3}\right)$ & & & & \\
$\mathrm{Max}$ & 41.8 & 22.9 & 57.0 & 165.3 \\
$\mathrm{Min}$ & 13.6 & 9.5 & 23.1 & 60.3 \\
Mean \pm s.d. & $24.2 \pm 11.0$ & $13.7 \pm 4.2$ & $44.8 \pm 14.8$ & $116.4 \pm 41.1$ \\
$\delta^{15} \mathrm{~N}(\%)$ & & & & \\
$\mathrm{Max}$ & -11.9 & 9.9 & 10.8 & -21.1 \\
Min & -22.3 & -11.4 & -12.3 & -46.9 \\
Mean \pm s.d. & $-17.9 \pm 4.0$ & $-2.0 \pm 7.0$ & $3.0 \pm 9.5$ & $-32.7 \pm 8.4$ \\
$\delta^{18} \mathrm{O}(\%)$ & & & & \\
Max & 66.6 & 103.2 & 111.4 & 91.1 \\
Min & 59.6 & 60.9 & 97.6 & 70.6 \\
Mean \pm s.d. & $63.2 \pm 2.5$ & $79.1 \pm 11.6$ & $103.9 \pm 6.9$ & $77.2 \pm 7.7$ \\
$\Delta^{17} \mathrm{O}(\%$ ) & & & & 37.4 \\
Max & 25.0 & 41.2 & 43.1 & 28.3 \\
Min & 22.5 & 20.0 & 37.3 & $31.1 \pm 3.2$ \\
Mean \pm s.d. & $24.0 \pm 1.1$ & $30.8 \pm 5.3$ & $40.2 \pm 2.7$ & \\
\hline
\end{tabular}

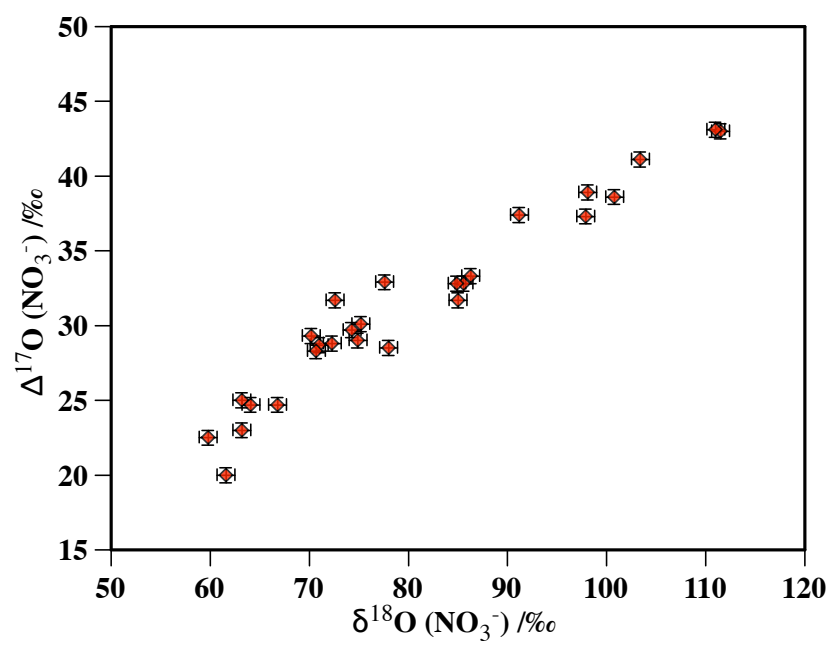

Fig. 3. Correlation between $\delta^{18} \mathrm{O}$ and $\Delta^{17} \mathrm{O}$.

and Solomon, 1986; de Zafra and Smyshlyaev, 2001; Funke et al., 2005; Orsolini et al., 2005; Stiller et al., 2005). According to these authors, $\mathrm{NO}_{\mathrm{x}}$ sources above the stratopause represent just a few per cent of the amount produced by in situ $\mathrm{N}_{2} \mathrm{O}$ oxidation (Santee et al., 2004) and only this latter source will be considered here.

$\mathrm{N}_{2} \mathrm{O}$ is destroyed in the stratosphere mainly by photolysis in the atmospheric UV "window region" between 185 and $220 \mathrm{~nm}$. This reaction accounts for $90 \%$ of its loss (Minschwaner et al., 1993) (Reaction R1). Chemical reactions with electronically excited oxygen atoms, $\mathrm{O}\left({ }^{1} \mathrm{D}\right)$, are an ad- ditional stratospheric $\mathrm{N}_{2} \mathrm{O}$ sink. This last reaction shows two exit channels, one "re-active" producing NO (Reaction R2a), the other "inert" leading to the formation of $\mathrm{N}_{2}$ and $\mathrm{O}_{2}(\mathrm{Re}-$ action R2b) (Cantrell et al., 1994; Sander et al., 2000).

$\mathrm{N}_{2} \mathrm{O}+h v \rightarrow \mathrm{N}_{2}+\mathrm{O}\left({ }^{1} \mathrm{D}\right)(90 \%)$

$\mathrm{N}_{2} \mathrm{O}+\mathrm{O}\left({ }^{1} \mathrm{D}\right) \rightarrow 2 \mathrm{NO}(6 \%)$

$\mathrm{N}_{2} \mathrm{O}+\mathrm{O}\left({ }^{1} \mathrm{D}\right) \rightarrow \mathrm{N}_{2}+\mathrm{O}_{2}(4 \%)$

$\mathrm{NO}$ formed through Reaction (R2a) reacts with $\mathrm{O}_{3}$ to form $\mathrm{NO}_{2}$.

$\mathrm{NO}+\mathrm{O}_{3} \rightarrow \mathrm{NO}_{2}+\mathrm{O}_{2}$

In the dark polar stratosphere, $\mathrm{NO}_{\mathrm{x}}$ is converted to stable $\mathrm{NO}_{\mathrm{y}}$ reservoir species:

$\mathrm{NO}_{2}+\mathrm{O}_{3} \rightarrow \mathrm{NO}_{3}+\mathrm{O}_{2}$
$\mathrm{NO}_{3}+\mathrm{NO}_{2} \rightarrow \mathrm{N}_{2} \mathrm{O}_{5}$
$\mathrm{ClO}+\mathrm{NO}_{2} \rightarrow \mathrm{ClONO}_{2}$

The winter denitrification of the Antarctic stratosphere is well established (Fahey et al., 1990; Santee et al., 1995; Van Allen et al., 1995). As daylight wanes, gas-phase $\mathrm{HNO}_{3}$ accumulates in the Antarctic stratosphere, mainly via reaction of dinitrogen pentoxide $\left(\mathrm{N}_{2} \mathrm{O}_{5}\right)$ with $\mathrm{H}_{2} \mathrm{O}$ on preexisting aerosols. At the end of winter, when stratospheric temperatures drop below $195 \mathrm{~K}$ (von Savigny et al., 2005), $\mathrm{ClONO}_{2}$ decomposition (hydrolysis or reaction with $\mathrm{HCl}$ ) becomes a 
significant source of gaseous nitric acid (Sander et al., 2003; S. Bekki, personal communication, 2006). When its vapor pressure reaches the threshold for formation of PSCs, gaseous $\mathrm{HNO}_{3}$ condenses to the solid phase as nitric acid trihydrate (NAT: $\mathrm{HNO}_{3} \cdot 3 \mathrm{H}_{2} \mathrm{O}$ ). Based upon satellite observations, Muscari et al. (2003) calculated for the entire 1995 polar vortex, which encompasses approximately the entirety of Antarctica (von Savigny et al., 2005), a drop in the $\mathrm{NO}_{\mathrm{y}}$ column corresponding to a total loss of $\Delta \mathrm{N}=(6.3 \pm 2.6) \times 10^{7} \mathrm{~kg}$. Assuming that this nitrogen is entirely in the form of $\mathrm{HNO}_{3}$ and completely lost into the troposphere (Muscari et al., 2003; Santee et al., 2004), such an injection corresponds to an increase of the $\mathrm{HNO}_{3}$ burden of $(28.4 \pm 11.7) \times 10^{7} \mathrm{~kg}$. Based on a stratospheric $\mathrm{HNO}_{3}$ climatology (Santee et al., 2004), denitrification occurs approximately, between July and November, and extends over an area equivalent to the entire Antarctic continent (area 16 million $\mathrm{km}^{2}$ ). Using the scale height of the atmosphere $\left(7.4 \mathrm{~km}\right.$ for $\left.\mathrm{T}_{\text {mean }}=250 \mathrm{~K}\right)$ and the relative mass of the troposphere (82\%, (Warneck, 1988)), we calculate a constant input above background of about $\mathrm{F}=(32.5 \pm 13.4) \mathrm{ng} \mathrm{m}^{-3} \mathrm{~d}^{-1}$ during this time period. Assuming a residence time $(\tau)$ of about a week for the nitrate in the troposphere and no in-situ production, at steady state the additional concentration in the tropospheric reservoir is $\mathrm{C}=\mathrm{F} \times \tau$, i.e. $(227 \pm 94) \mathrm{ng} \mathrm{m}^{-3}$. Assuming that this contribution is partitioned equally between gaseous nitrate and particulate nitrate, as observed at DDU (Jourdain and Legrand, 2002), an additional aerosol concentration of about (114 \pm 47$) \mathrm{ng} \mathrm{m}^{-3}$ can be expected based on the stratospheric denitrification process. This is a reasonable additional loading above the background concentration in comparison with the increase of about $145 \mathrm{ng} \mathrm{m}^{-3}$ observed from July to December and the crude character of this calculation, which ignores latitudinal transport. A similar conclusion was reached by Wagenbach et al. (1998) using a different approach. It is therefore conceivable to consider PSCs as a possible cause of the nitrate increase observed from July through December.

Air mass exchange between the stratosphere and troposphere (STE) offers another mechanism for injecting stratospheric $\mathrm{HNO}_{3}$ into the troposphere. Using cosmogenic/radioactive tracers $\left({ }^{3} \mathrm{H},{ }^{7} \mathrm{Be},{ }^{10} \mathrm{Be},{ }^{210} \mathrm{~Pb}\right)$, Wagenbach et al. (1998) concluded that $\mathrm{S} / \mathrm{T}$ exchange should enhance ground level concentrations by at most $35 \mathrm{ng} \mathrm{m}^{-3}$ (in February), with a total contribution representing $31 \%$ of the PSC source. STE seems therefore inadequate to explain most of the observed concentration increase.

\subsubsection{The snowpack source}

With the discovery of the photochemical production of $\mathrm{NO}_{\mathrm{x}}$ within the firn layer (Honrath et al., 1999; Jones et al., 2000, 2001; Davis et al., 2001, 2004a; Honrath et al., 2002), it has become clear that the polar cap can be a significant source of nitrate (Jacobi et al., 2000; Jones et al., 2001; Weller et al., 2002). In their study, Wagenbach et al. (1998) considered snowpack emissions as a source of atmospheric nitrate, but because of incomplete data at the time, they did not conclude this source to be significant. Since their work, a better understanding of the fate of nitrate in snow has been achieved. At high accumulation sites $\left(>30 \mathrm{~cm}_{\text {of }}\right.$ snow $\mathrm{a}^{-1}$ ), nitrate and its isotopic signature are rather well conserved (Röthlisberger et al., 2000, 2002; Burkhart et al., 2004; Hastings et al., 2004;). On the other hand, at low accumulation sites like Dome $\mathrm{C}$ (snow accumulation $\approx 10 \mathrm{~cm} \mathrm{a}^{-1}$ ), photoemission of $\mathrm{NO}_{\mathrm{x}}$ and evaporation of nitric acid dominate, leading to a sharp decrease in firn concentrations (Röthlisberger et al., 2000). This process was also observed during the ISCAT 2000 project at South Pole (Dibb et al., 2004).

All inland sites with low snow accumulation $\left(<20 \mathrm{~cm} \mathrm{a}^{-1}\right)$ show roughly the same sharp decrease in nitrate concentration (Mayewski and Legrand, 1990; Röthlisberger et al., 2000; Dibb et al., 2004; Udisti et al., 2004) with values dropping from almost $1000 \mathrm{ng} \mathrm{g}^{-1}$ at the surface down to $40-60 \mathrm{ng} \mathrm{g}^{-1}$ at few cm depth. In order to estimate the correct emission flux into the atmosphere, the rate for such a decrease needs to be evaluated. In the Dome $\mathrm{C}$ records (Röthlisberger et al., 2000; Udisti et al., 2004), background values are reached at a depth equivalent to roughly a year of accumulation, $(10 \mathrm{~cm}$ depth). On the other hand, at South Pole (Dibb et al., 2004), background concentrations are reached at a depth equivalent of $1 / 3$ of the annual accumulation (also $10 \mathrm{~cm}$ depth). These observations seem to indicate that the loss of nitrate in surface snow is not a continuous process that extends all year-round. Photolysis and thermodynamical equilibrium are the two major processes controlling the nitrate concentration in snow (Mulvaney et al., 1998; Röthlisberger et al., 2000; Honrath et al., 2000a; Jones et al., 2000; Burkhart et al., 2004; Dibb et al., 2004; Blunier et al., 2005). Photolysis is active only during the polar day from October to March. For the latter process, Röthlisberger et al. (2002) suggested that surface uptake and conservation seem to be dominated by equilibrium process in determining the concentration of nitrate in snow. Since this process has a strong negative temperature dependence, escape of $\mathrm{HNO}_{3}$ from the surface snow grains is expected to be at maximum when temperatures rise from $-60^{\circ} \mathrm{C}$ in September to $-30^{\circ} \mathrm{C}$ in December (http://polarmet.mps.ohio-state.edu/ RIME-01/pdf_docs/dc14_report05.pdf). We can therefore reasonably assume that the entire loss (photolysis and evaporation) reaches its maximum during this period of 90 days. Based on published concentration profiles at Vostok, Dome C and South Pole (Mayewski and Legrand, 1990; Röthlisberger et al., 2000; Dibb et al., 2004), we estimate an average nitrate loss of $\Delta\left[\mathrm{NO}_{3}^{-}\right]_{\text {average }}=(300 \pm 100) \mathrm{ng} \mathrm{g}^{-1}$, occurring in the first $(10 \pm 5) \mathrm{cm}$ of snow. Limiting this process to an area where accumulation is lower than $\approx 20 \mathrm{~cm}$ of snow per year, i.e. 6 million $\mathrm{km}^{2}$ (Wagenbach et al., 1998), we calculate a nitrate emission source of $\Delta \mathrm{N}=(1.2 \pm 1.0) \times 10^{7} \mathrm{~kg}$ of $\mathrm{NO}_{\mathrm{y}}$ using a surface snow density of $0.3 \mathrm{~g} \mathrm{~cm}^{-3}$. Such an estimation has to be compared with $\Delta \mathrm{N}=(6.3 \pm 2.6) \times 10^{7} \mathrm{~kg}$ for 
the PSCs source calculated by Muscari et al. (2003) or $\mathrm{NO}_{\mathrm{x}}$ snow emission of $\Delta \mathrm{N}=0.76 \times 10^{7} \mathrm{~kg}$ estimated by Jones et al. (2001). Because snow is a surface source and because strong temperature inversions are experienced in summer in the Antarctic boundary layer (König-Langlo et al., 1998), this source can easily accommodate the concentration increase from July to December observed at DDU. If such a quantity is emitted in 90 days (late springtime/yearly summertime), into a $1000 \mathrm{~m}$ tropospheric column, a concentration of $\Delta\left[\mathrm{HNO}_{3}\right] \approx 38 \mathrm{ng} \mathrm{m}^{3} \mathrm{~d}^{-1}$ is added to the background situation over the entire Antarctic $\left(16\right.$ million $\left.\mathrm{km}^{2}\right)$, assuming a total conversion of $\mathrm{NO}_{\mathrm{y}}$ to nitric acid and neglecting any meridional transport. This increase is similar to the one calculated for the PSC source. Using a nitrate lifetime of one week and a 1:1 partitioning between gaseous and particulate nitrate, we would expect an increase of the particulate nitrate concentration of ca. $133 \mathrm{ng} \mathrm{m}^{-3}$, in good agreement with the observed increase of $135 \mathrm{ng} \mathrm{m}^{-3}$ from September to December. Because of the role played by temperature and sunlight, snowpack emissions are not expected to be significant outside the period between October and February.

\subsubsection{The continental source}

Due to the remoteness of the Antarctic continent from continental land masses, supply of continental nitrogen oxides species is expected to come from the free troposphere via long-range transport of gases and aerosols. PAN and alkyl nitrates, formed over continents, are relatively stable reservoirs of $\mathrm{NO}_{\mathrm{x}}$. With $\mathrm{HNO}_{3}+\mathrm{p}-\mathrm{NO}_{3}^{-}$representing $22 \%$ between February and November and $66 \%$ between November and December of the coastal Antarctic $\mathrm{NO}_{\mathrm{y}}$ (Weller et al., 2002), continental organic-nitrate can potentially be the supply reservoir for $\mathrm{NO}_{2}$. In a study of PAN at Neumayer station in February 1999, Jacobi et al. (2000) concluded that thermal decomposition of PAN was probably not sufficient to maintain the observed $\mathrm{NO}_{\mathrm{x}}$ mixing ratios at this site. Regarding alkyl nitrates, the same conclusion can be drawn. Using the upper limit of loss rate of $10^{-6} \mathrm{~s}^{-1}$ given by Talukdar et al. (1997) and a total concentration of C1-C3 alkyl nitrate of $13 \mathrm{pmol} \mathrm{mol}^{-1}$ (Weller et al., 2002), one can calculate a maximum of $\mathrm{NO}_{\mathrm{x}}$ production from the decomposition of these species of ca. $0.04 \mathrm{pmol} \mathrm{mol}^{-1} \mathrm{~h}^{-1}$, which has to be compared with the $\mathrm{NO}_{\mathrm{x}}$ decay rates of approximately $0.35 \mathrm{pmol} \mathrm{mol}^{-1} \mathrm{~h}^{-1}$ measured at Neumayer (Jacobi et al., 2000), pinpointing the inadequacy of the alkyl nitrate source. Similarly, using ${ }^{210} \mathrm{~Pb}$ as a tracer of continental emissions, Wagenbach et al. (1998) estimated that the continental aerosol source could only account for at most $16 \mathrm{ng} \mathrm{m}^{-3}$ of the nitrate aerosol loading, suggesting that continental aerosols do not contribute significantly to the nitrate budget. In summary, the continental source seems to be a possible candidate for the background concentration but unlikely the source for the July/August and November/December peaks.

\subsection{Atmospheric dynamic and transport}

Santacesaria et al. (2001) provided a detailed statistical analysis of PSC occurrence above DDU. From their observations, after the end of July, PSCs are often observed within $1 \mathrm{~km}$ of the tropopause. A weak tropopause barrier generally characterizes this time of the year (König-Langlo et al., 1998) and injection of stratospheric material into the troposphere is facilitated at the end of July. Tritium $\left({ }^{3} \mathrm{H}\right)$ contained in water is a reasonable tracer of stratospheric water. ${ }^{3} \mathrm{H}$ is mainly produced in the lower stratosphere by the interaction of cosmic rays and exhibits a much higher abundance in stratospheric water vapor than tropospheric water (Ehhalt et al., 2002). At Halley Bay station (Antarctica), ${ }^{3} \mathrm{H}$ in precipitation peaks during period 3 (July to October) (Wagenbach et al., 1998), suggesting the predominance of stratospheric material injection into the troposphere during this period of the year and a rapid transfer to the ground.

König-Langlo et al. (1998) have discussed in details the meteorology of DDU. Year-round, ground level air mass flows are characterized by katabatic winds where large quantities of cold and dry air are drained from the central plateau of Antarctica. Vertical profiles of meridional winds show that such flows take place up to an altitude of approximately $2 \mathrm{~km}$ and are well organized throughout the year. A similar shear in the wind field structure is observed for the zonal winds, with ground level flows governed by easterly wind drift, switching to westerly above $2 \mathrm{~km}$ height. This particularity of the DDU area strongly limits direct advections of oceanic air masses and further suggests that the Antarctic plateau is the main source of air reaching the DDU station.

\subsection{Isotopic constraints on nitrate sources}

In the following sections, we use the measured nitrate isotopic composition to qualitatively constrain the three possible sources mentioned above. Because little is known about equilibrium and kinetic fractionation coefficients between nitrogen oxides and phases, rigorous quantitative interpretation is limited. Only extreme and characteristic isotopic compositions are therefore used to tentatively assign nitrate sources.

\subsubsection{Nitrogen isotopes in stratospheric $\mathrm{NO}_{\mathrm{x}}$ and nitrate}

Neglecting the upper atmospheric contribution (i.e. $\mathrm{N}_{2}$ photo-ionization and photo-dissociation), the nitrogen isotope composition of stratospheric $\mathrm{NO}_{\mathrm{x}}$ can be estimated from the degree of $\mathrm{N}_{2} \mathrm{O}$ destruction in the stratosphere and the isotopic fractionation associated with the reaction $\mathrm{N}_{2} \mathrm{O}+\mathrm{O}\left({ }^{1} \mathrm{D}\right)$ (Kaiser et al., 2002a; Toyoda et al., 2004). After mathematical calculation and integration, one obtains (see Appendix A for details):

$$
\overline{\delta^{15} \mathrm{~N}(\mathrm{NO})}=\left(1+{ }^{15} \varepsilon_{\mathrm{R} 2 \mathrm{a}}\right) \frac{1+\delta^{15} \mathrm{~N}\left(\mathrm{~N}_{2} \mathrm{O}\right)_{0}}{1+{ }^{15} \varepsilon_{\text {sinks }}} \frac{1-f^{1+{ }^{15} \varepsilon_{\text {sinks }}}}{1-f}-1
$$


In this analytical expression, the first term in brackets describes the fractionation due to Reaction (R2a) while the second term expresses the fractionation of $\mathrm{N}_{2} \mathrm{O}$ by all its sink processes. Because PSCs can be formed up to an altitude of $25 \mathrm{~km}$ above DDU (Santacesaria et al., 2001) and slowly subside from this altitude, we use the average fractionation constant observed in January for Antarctica by Toyoda et al. (2004): ${ }^{15} \varepsilon_{\text {sinks }}=-31 \%$. For $f$, representing the fraction of $\mathrm{N}_{2} \mathrm{O}$ transformed into $\mathrm{NO}$ (see Appendix A), we use the value of $(0.15 \pm 0.06)$, corresponding to a mixing ratio of $\mathrm{N}_{2} \mathrm{O}$ of $(50 \pm 20) \mathrm{nmol} \mathrm{mol}^{-1}$ (altitude $\approx 25 \mathrm{~km}$ ) (Toyoda et al., 2004), and initial stratospheric $\delta^{15} \mathrm{~N}\left(\mathrm{~N}_{2} \mathrm{O}\right)_{0}$ of $(6.7 \pm 0.1) \%$ with $\left[\mathrm{N}_{2} \mathrm{O}\right]_{0}=(320 \pm 1) \mathrm{nmol} \mathrm{mol}^{-1}$ (Kaiser et al., 2003a; Röckmann and Levin, 2005). This calculation yields an average stratospheric $\delta^{15} \mathrm{~N}(\mathrm{NO})=(19 \pm 3) \%$, the uncertainty being due to the parameter: $f( \pm 40 \%)$. Adopting a single value for ${ }^{15} \varepsilon_{\text {sinks }}$ neglects possible seasonal and altitude variations (Kaiser et al., 2006), but does not change the result that the accumulated stratospheric NO is enriched relative to tropospheric $\mathrm{N}_{2} \mathrm{O}$. Moreover, the above calculation neglects the fact that ${ }^{15} \varepsilon_{\mathrm{R} 2 \mathrm{a}}$ is not fully expressed under the influence of mixing and diffusion, so that the actual $\delta^{15} \mathrm{~N}(\mathrm{NO})$ will actually be larger than calculated from Eq. (3). Considering that more than $90 \%$ of $\mathrm{NO}_{\mathrm{y}}$ is eliminated from the stratosphere during the denitrification process (Fahey et al., 1990; Muscari et al., 2003), it is expected that $\delta^{15} \mathrm{~N}\left(\mathrm{p}-\mathrm{NO}_{3}^{-}\right) \approx \delta^{15} \mathrm{~N}\left(\mathrm{HNO}_{3}\right) \approx \delta^{15} \mathrm{~N}(\mathrm{NO})=(19 \pm 3) \%$.

\subsubsection{Oxygen isotopes in stratospheric nitrate}

Michalski et al. (2003) developed the first theoretical framework for understanding of the triple oxygen isotopic composition of atmospheric nitrate. The theory is based on the transfer of the oxygen isotope anomaly of $\mathrm{O}_{3}$ to $\mathrm{NO}_{\mathrm{x}}$ and subsequently to $\mathrm{HNO}_{3}$. The first step relies on the oxygen isotope transfer during photostationary equilibrium between $\mathrm{NO}_{\mathrm{x}}$ and $\mathrm{O}_{3}$. Based on branching ratio measurements of ozone formation reactions, Lyons (2001) computed that the $\Delta{ }^{17} \mathrm{O}$ value of the terminal oxygen atom in ozone would be more than double that of bulk ozone (which implies a strong negative anomaly for the central oxygen atom). Lyons (2001) also assumed that $\mathrm{NO}$ would only react with the terminal $\mathrm{O}$ atom, so that under steady-state conditions the $\Delta^{17} \mathrm{O}$ value of stratospheric $\mathrm{NO}_{2}$ would be $80 \%$ or greater. In contrast, Michalski et al. (2003) suggested that molecular beam experiments could be interpreted as an indication for a statistical participation of the three oxygen atoms of ozone in its reaction with NO (van den Ende et al., 1982; van den Ende and Stolte, 1984), which would lead to a direct transfer of the ozone isotope anomaly to the second $\mathrm{O}$ atom in the product $\mathrm{NO}_{2}$. With this assumption, the intramolecular distribution of the ozone isotope anomaly does not play a role. Finally, Zahn et al. (2006) assumed that that the intramolecular ${ }^{17} \mathrm{O}$ distribution in ozone follows that of ${ }^{18} \mathrm{O}$ and that $\mathrm{NO}$ only reacts with the terminal $\mathrm{O}$ atom in ozone, from which they calculated $\Delta^{17} \mathrm{O}\left(\mathrm{NO}_{2}\right)=40 \%$ in the stratosphere. None of these theoretical assumptions have been backed up by data and one should also keep in mind that the molecular beam reactions of (van den Ende et al., 1982; van den Ende and Stolte, 1984) may not be relevant to atmospheric conditions as the translational kinetic energy of the parent molecules were well above the thermal conditions encounter in the lower atmosphere. However, an indication that the central $\mathrm{O}$ atom of $\mathrm{O}_{3}$ does indeed participate in its reaction with NO comes from a set of laboratory experiments (Savarino et al., 2007 ${ }^{1}$ ) done at room temperature in an atmospheric chamber. In the wait of a definitive answer for this transfer coefficient, we chose to vary it between the extreme values of 0.8 and 1.2 (Zahn et al., 2006). No data are currently available for the isotopic composition of stratospheric Antarctic ozone. A re-evaluation of the most-recent isotope measurements for stratospheric ozone from the Northern Hemisphere with a three isotope coefficient of 0.52 gives $(34.2 \pm 3.7) \%$, with a range from 25.8 to $40.5 \%$ (Krankowsky et al., 2000; Mauersberger et al., 2001; Lämmerzahl et al., 2002). Combining these observations with the range of $\Delta^{17} \mathrm{O}$ transfer coefficients from 0.8 to $1.2, \Delta^{17} \mathrm{O}\left(\mathrm{NO}_{2}\right)$ is expected to vary in the range from $27.3 \%$ to $41.0 \%$ on average, with most extreme values of 20.7 and $48.7 \%$. This estimation ignores the possible influence of $\mathrm{ClO} / \mathrm{BrO}$ on the $\mathrm{NO}$ oxidation (Kerher et al., 1997).

Two oxidation pathways lead to the formation of nitric acid in the dark polar winter stratosphere (Fig. 4). The first one involves the heterogeneous hydrolysis of $\mathrm{N}_{2} \mathrm{O}_{5}$ :

$\mathrm{N}_{2} \mathrm{O}_{5}+\mathrm{H}_{2} \mathrm{O}_{\mathrm{ads}} \rightarrow 2 \mathrm{HNO}_{3}$

Oxygen atoms mass balance shows that this route leads to $\Delta^{17} \mathrm{O}\left(\mathrm{HNO}_{3}\right)=5 / 6 \Delta^{17} \mathrm{O}\left(\mathrm{NO}_{2}\right)$ (Michalski et al., 2003), thus in the range of 17.2 to $40.5 \%$. The other reaction pathway involves $\mathrm{ClONO}_{2}$ and $\mathrm{BrONO}_{2}$ (Hanson and Ravishankara, 1991; Sander et al., 2003) when vortex temperature falls below $195 \mathrm{~K}$ in winter:

$$
\begin{aligned}
& \mathrm{X}+\mathrm{O}_{3} \rightarrow \mathrm{XO}+\mathrm{O}_{2} \\
& \mathrm{XO}+\mathrm{NO}_{2} \rightarrow \mathrm{XONO}_{2} \\
& \mathrm{XONO}_{2}+(\mathrm{HCl})_{\mathrm{ads}} \rightarrow \mathrm{HOX}+\mathrm{HNO}_{3}
\end{aligned}
$$

where $\mathrm{X}=\mathrm{Cl}$ or $\mathrm{Br}$. Morin et al. (2007) showed that, in this case, because halogen radicals abstract directly a terminal oxygen atom in ozone during Reaction (R8) (Toohey et al., 1988; Zhang et al., 1997) and that these atoms are more enriched in heavy isotopes than the bulk ozone molecule (Janssen, 2005), $\quad \Delta^{17} \mathrm{O}(\mathrm{XO})=\Delta^{17} \mathrm{O}\left(\mathrm{O}_{3}\right)_{\text {terminal }}=(20.7$ to 48.7)\%o using the intramolecular oxygen isotope distribution

\footnotetext{
${ }^{1}$ Savarino, J., Bhattacharya, S., Baroni, M., and Doussin, J.-F.: Oxygen isotope anomalies transfer from $\mathrm{O}_{3}$ to $\mathrm{NO}_{2}$ in the $\mathrm{NO}+\mathrm{O}_{3}$ reaction, in preparation, 2007.
} 

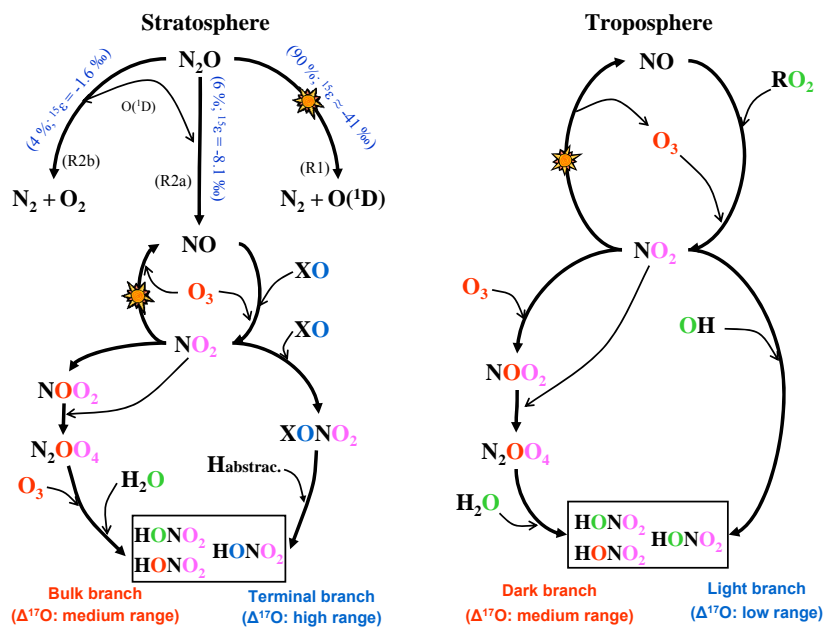

Fig. 4. Chemical cycling of nitrogen oxides $\left(\mathrm{NO}_{\mathrm{x}}\right)$ in the stratosphere and troposphere. As described in the text, the $\delta^{15} \mathrm{~N}$ signature of stratospheric NO is derived from the dissociation reactions of $\mathrm{N}_{2} \mathrm{O}$, the primary stratospheric $\mathrm{NO}_{\mathrm{x}}$ source (top left). Then, $\mathrm{NO}$ enters the chemical interactions cycle with ozone and halogen oxides (bottom left) and the resulting $\mathrm{NO}_{2}$ acquires an isotope anomaly dependent on the reactivity of NO with respect to oxidant species $\left(\mathrm{O}_{3}, \mathrm{XO}\right) . \mathrm{NO}_{2}$ is then converted in to nitric acid through different pathways, incorporating different amounts of $\mathrm{O}_{3}$-derived oxygen atoms, hence leading to varying isotopic anomalies. This scheme leads to the high range of $\Delta^{17} \mathrm{O}$ values. The tropospheric scheme is based on previous work of Michalski et al. (2003) where nitrate derives its oxygen isotopic anomaly only from ozone. Nighttime and daytime $\mathrm{NO}_{\mathrm{x}}$ chemistry lead to medium and low ranges of $\Delta^{17} \mathrm{O}$ values, respectively. Oxygen atoms are color coded according to their isotopic anomaly, determined by the reaction between parent molecules.

of Zahn et al. (2006). Thus, we have for the nitric acid made off $\mathrm{XONO}_{2}$ (Morin et al., 2007):

$\Delta^{17} \mathrm{O}\left(\mathrm{HNO}_{3}\right)=1 / 3 \Delta^{17} \mathrm{O}(\mathrm{XO})+2 / 3 \Delta^{17} \mathrm{O}\left(\mathrm{NO}_{2}\right)$

which gives an estimated range of 18 to $43 \%$.

Such a range should be used with caution. One should realize that large uncertainties exist in the transfer of $\mathrm{O}_{3}$ oxygen anomaly to the $\mathrm{HNO}_{3}$. This transfer depends on relative kinetic rate between the two heterogeneous Reactions (R7) and (R10), the transfer mechanism of Reactions (R3) and (R7), the internal distribution of isotope in ozone and may be on some unknown oxygen isotopic exchange reaction between $\mathrm{NO}_{\mathrm{x}}$ and oxygen-bearing reservoirs (Zahn et al., 2006). Thus, still today, it appears relatively speculative to predict with a high level of confidence the range of the oxygen isotope anomaly of nitric acid produced in the stratosphere. Nevertheless, the polar stratosphere seems to be the only place where the oxygen isotope anomaly of nitrate can reach its highest value for two reasons: firstly, it is in this part of the atmosphere that the highest $\mathrm{O}_{3}$ isotopic anomalies have been recorded so far and secondly polar strato- spheric $\mathrm{NO}_{\mathrm{y}}$ chemistry has a natural propensity to transfer more anomaly from ozone to nitric acid via the predominance of $\mathrm{N}_{2} \mathrm{O}_{5}$ and $\mathrm{ClONO}_{2}$ formation pathways.

\subsubsection{Nitrogen isotopes of snowpack emissions}

Recently Blunier et al. (2005) performed a survey of the $\delta^{15} \mathrm{~N}$ of nitrate in DC snow. They observed a sharp increase in $\delta^{15} \mathrm{~N}$, concomitant with the depletion of nitrate in the snow. Within the first $15 \mathrm{~cm}$ of snow, the $\delta^{15} \mathrm{~N}\left(\mathrm{NO}_{3}^{-}\right)$rises dramatically from +10 to $+200 \%$ o. From this observation, Blunier et al. (2005) deduced that the post-depositional effect responsible for the removal of nitrate had an apparent net effect of $\varepsilon_{\text {snow }}=-53.9 \%$ o.

Blunier et al.'s data indicate that $\mathrm{NO}_{\mathrm{x}}$ and nitric acid emitted by the snow in the central plateau of Antarctica should be depleted in ${ }^{15} \mathrm{~N}$ isotopes. Applying an isotopic Rayleigh-type fractionation for Dome C snowpack with $\varepsilon_{\text {snow }}=-53.9 \%$ o(Blunier et al., 2005), the average $\delta^{15} \mathrm{~N}\left(\mathrm{HNO}_{3}\right)_{\text {emitted }}$ is

${\overline{\delta^{15} \mathrm{~N}\left(\mathrm{HNO}_{3}\right)}}_{\mathrm{emitted}}=\left(1+\delta^{15} \mathrm{~N}_{0}\right) \frac{1-f^{15} \varepsilon_{\text {snow }}+1}{1-f}-1$

with $f$, the mass fraction of the residual nitrate remaining in the snow and $\delta^{15} \mathrm{~N}_{0}$, the nitrogen isotopic composition of surface snow nitrate. Taking $f=0.7 \pm 0.2$ (i.e., a $(30 \pm 20) \%$ loss of nitrate during November-December months, see Sect. 4.1.2.), and $\delta^{15} \mathrm{~N}_{0} \approx 12 \%$ (Blunier et al., 2005), one find average $\delta^{15} \mathrm{~N}$ of $\mathrm{HNO}_{3}$ emitted in the order of $(-34 \pm 7) \%$. No published atmospheric nitrate ${ }^{15} \mathrm{~N}$ have ever displayed such low $\delta^{15} \mathrm{~N}$ values (Heaton et al., 2004, and references therein), with the notable exception of Antarctica and we are unaware of a physical or chemical process in the atmosphere capable of generating such ${ }^{15} \mathrm{~N}$-depleted nitrate.

\subsubsection{Oxygen isotopes of snowpack emissions}

The comparison between seasonal composition in aerosol, surface snow and snow pit at South Pole indicates that the isotopic composition of atmospheric nitrate is transferred to surface snow (McCabe et al., 2005a). The annual average of the first snow layer of a snow pit (snow layer 2003), $\Delta^{17} \mathrm{O}\left(\mathrm{NO}_{3}^{-}\right)=(28.8 \pm 3.5) \%$, compared well with the annual average, $(29.3 \pm 3.7) \%$, obtained with monthly surface snow samples collected during the wintering-over in 2004. Such observations coupled with laboratory experiments (McCabe et al., 2005b) indicate a good preservation of $\Delta^{17} \mathrm{O}\left(\mathrm{NO}_{3}^{-}\right)$in snow. A model study focusing on emission fluxes (Wolff et al., 2002) suggested that photolysis and thermodynamically controlled processes (e.g. diffusion) are quantitatively equivalent in snow. Therefore, it can be deduced that emission of $\mathrm{NO}_{\mathrm{y}}$ from the snow will be essentially in the form of $\mathrm{NO}_{\mathrm{x}}$ and $\mathrm{HNO}_{3}$ in equal proportion. The $\mathrm{NO}_{\mathrm{x}}$ will lead to a summer tropospherictype oxygen isotopic signature of nitrate through nitrate 
formation in the troposphere during transport from inland to the coast, i.e. $\Delta^{17} \mathrm{O}\left(\mathrm{NO}_{3}^{-}\right)$tropo summer $\approx(26 \pm 2) \%$ o (McCabe et al., 2005a), whereas reemitted $\mathrm{HNO}_{3}$ should have a mean value of $\Delta^{17} \mathrm{O}\left(\mathrm{NO}_{3}^{-}\right)_{\text {nnow }} \approx(30 \pm 2) \%$ corresponding to the isotopic composition of nitrate at the surface of the snowpack. Overall, summing up these two contributions should yield for the inorganic nitrate reaching the coast: $\Delta^{17} \mathrm{O}\left(\mathrm{NO}_{3}^{-}\right)=28.0 \pm 4 \%$.

\subsubsection{Nitrogen isotopes of continental sources}

In other parts of the world, $\delta^{15} \mathrm{~N}$ ranges between -20 to $+20 \%$ in particulate nitrate (Hoering, 1957; Moore, 1977; Freyer, 1978, 1991; Heaton, 1987; Fogel and Paerl, 1993; Freyer et al., 1996; Koba et al., 1997; Pichlmayer et al., 1998; Russel et al., 1998; Burns and Kendall, 2002; Campbell et al., 2002; Hastings et al., 2003), nitrate in Arctic snow or ice (Hastings et al., 2004, 2005; Heaton et al., 2004), alpine ice (Freyer et al., 1996), and $\mathrm{NO}_{\mathrm{x}}$ (Moore, 1977; Heaton, 1990). We note that this range encompasses the stratospheric values deduced in Sect. 4.2.1. We suggest therefore that $\delta^{15} \mathrm{~N}$ of nitrate is not a suitable tracer to discriminate between stratospheric and tropospheric sources of nitrate, in contradiction to the study of Wagenbach et al. (1998).

\subsubsection{Oxygen isotope anomaly in the troposphere}

Tropospheric ozone generally has a lower isotopic anomaly than stratospheric ozone (Krankowsky et al., 1995; Irion et al., 1996; Johnston and Thiemens, 1997; Mauersberger et al., 2001; Lämmerzahl et al., 2002). Tropospheric-produced nitrate is therefore expected to have lower isotopic anomalies than nitrate produced in the stratosphere (Fig. 4). Recently, Morin et al. (2007) measured a high anomaly in tropospheric nitrate samples from the Arctic. Indeed, in the springtime Arctic boundary layer, characterized by significant levels of $\mathrm{BrO}, \mathrm{BrONO}_{2}$ hydrolysis can become a major route of $\mathrm{HNO}_{3}$ formation. As in the case of stratospheric chemistry, such oxidation pathways involving halogen chemistry can enhance the oxygen isotopic anomaly transfer from precursors to products. However, satellite-derived tropospheric $\mathrm{BrO}$ maps show that the DDU area never experiences significant $\mathrm{BrO}$ blooms (Richter et al., 2002). The DMSO/DMS ratio at DDU does show an anomalous increase which may be related to the fast oxidation of DMS to DMSO by $\mathrm{BrO}$ (von Glasow and Crutzen, 2004), but only in August (M. Legrand, personal communication, 2006). In addition, air masses reaching DDU mainly originate from the interior of the continent (König-Langlo et al., 1998) and are not exposed to marine $\mathrm{BrO}$-enriched conditions for a long period. The tropospheric halogen chemistry seems therefore to be marginal, but needs further investigation. During nighttime formation of $\mathrm{HNO}_{3}$, more oxygen atoms of ozone are incorporated. Based on Michalski's observations, $\Delta^{17} \mathrm{O}$ ranges from 28 to $30 \%$ and 22 to $25 \%$ in the troposphere for winter-

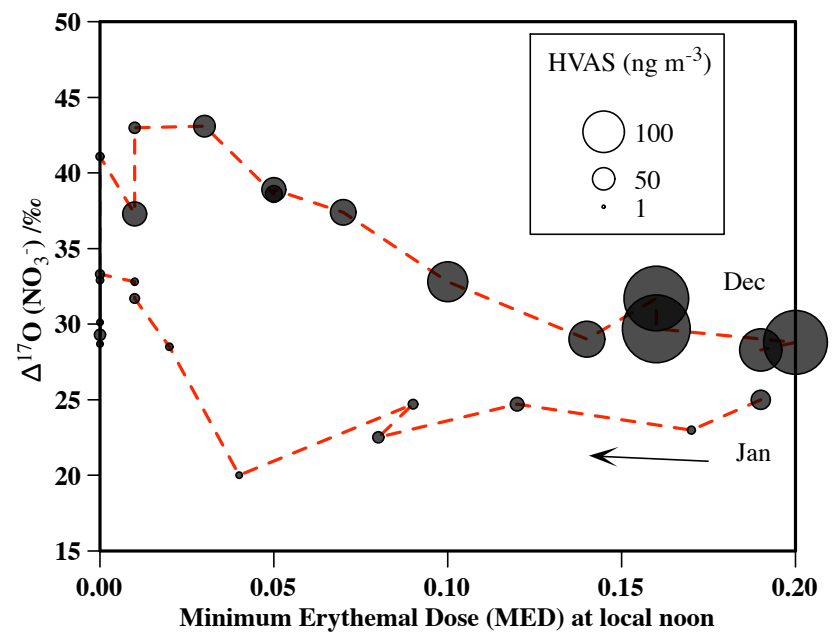

Fig. 5. Yearly cycle of $\Delta^{17} \mathrm{O}\left(\mathrm{NO}_{3}^{-}\right)$as a function of local insolation (proportional to daily minimum erythemal dose (MED)). The size of the circles refers to the concentration of atmospheric nitrate for each sample. Maximum MED correspond to summer conditions, while minimum MED (0) correspond to winter conditions. $\Delta^{17} \mathrm{O}$ shows a tendency to higher values in winter and lower values in summer, consistently with the developments by Michalski et al. (2003) and the details given in the text. Late winter values (increasing MED) are shifted to higher $\Delta^{17} \mathrm{O}$ values because of the influence of the stratosphere: the denitrification occurring in midwinter leads to a sudden increase by ca. $8 \%$ in $\Delta^{17} \mathrm{O}$ values, with a small concurrent concentration increase (Period 3, see text for details). The large concentration peak (largest circles in the figure) is still isotopically influenced by the stratospheric source of nitrate to a lower extent, due to snowpack processing and tropospheric oxidation mechanisms for re-emitted $\mathrm{NO}_{x}$ (Period 4, see text for details).

time and summertime, respectively (Michalski et al., 2003) (see Fig. 4 for the complete scheme). In the absence of more systematic surveys of tropospheric nitrate oxygen isotopic composition, we assume that Michalski's approach is also valid at DDU and any values outside these ranges is an indication of a possible different process.

\subsection{Seasonal variations}

Summarizing all the information developed in the latter sections, we obtain the following main estimations:

- stratospheric PSC nitrate should possess an isotopic composition of $\delta^{15} \mathrm{~N}\left(\mathrm{NO}_{\mathrm{y}}\right)_{\text {strato }} \approx(19 \pm 3) \%$ and $\Delta^{17} \mathrm{O}\left(\mathrm{NO}_{\mathrm{y}}\right)_{\text {strato }}=(17-43) \%$,

- the isotopic composition of tropospheric nitrate is best constrained by $\delta^{15} \mathrm{~N}\left(\mathrm{HNO}_{3}\right)=(-20$ to +20$) \%$ and $\Delta{ }^{17} \mathrm{O}$ from 28 to $30 \%$ and 22 to $25 \%$ o for wintertime and summertime, respectively, ignoring any possible halogen chemistry at ground level,

- snow-emitted nitrate (including nitrate formed by conversion of its snow-emitted precursors such as $\mathrm{NO}_{\mathrm{x}}$ ) 
is expected to possess $\delta^{15} \mathrm{~N}\left(\mathrm{NO}_{3}^{-}\right)_{\text {emitted }} \approx-34 \pm 7 \%$ and $\Delta^{17} \mathrm{O}\left(\mathrm{NO}_{3}^{-}\right)_{\text {emitted }} \approx 28 \%$,

- nitrate source fluxes from snow and PSCs are both compatible with late spring nitrate concentration peaks,

- air mass meteorology at DDU is dominated all yearround by inland drift,

- subsidence and penetration of PSCs into the troposphere occur during the wintertime/springtime transition when the tropopause barrier is weak and the lower stratosphere very cold.

\subsubsection{Periods 1 and 2}

From January to July, corresponding to our period 1 and 2, Wagenbach et al. (1998), using radionuclide tracers, estimated the relative contribution of tropospheric and stratospheric sources to be roughly 1:1, with some variability from month to month. At this time of the year, the stratospheric input is the result of air mass intrusions. Based on our data, we are unable to prove or disprove this estimate. The nitrogen isotopic signature of tropospheric nitrate overlapping the stratospheric range (Moore, 1974; Heaton et al., 2004), it is impossible from our dataset to distinguish the exact influence of these two reservoirs. We cannot draw firm conclusions about the slow increase in $\delta^{15} \mathrm{~N}$ from -20 to $10 \%$ o between January and end of August. We note however that during this period, the average temperature drops from 0 to $-15^{\circ} \mathrm{C}$ and kinetic isotopic effects associated with inter coupling of $\mathrm{NO}_{\mathrm{y}}$ species and a decline of photochemistry might be an explanation for this trend in $\delta^{15} \mathrm{~N}$ values.

The oxygen isotope anomaly indicates two different regimes, with $\Delta^{17} \mathrm{O}$ ranging between (22-25)\%o and (2033 )\%o for summer (January-March) and fall (March- mid July), respectively. Figure 5 exhibits the oxygen isotopic anomaly versus the minimum erythemal UV doses (MED) received at ground level in 2001 in DDU. Erythemal UV doses are used here as an indicator of sunlight intensity. As sunlight wanes, $\Delta^{17} \mathrm{O}\left(\mathrm{NO}_{3}^{-}\right)$increases. $\Delta^{17} \mathrm{O}$ ranges observed during period 1 and 2 (lower line in Fig. 6) are in good agreement with the ones reported by Michalski et al. (2003) for summer and winter, respectively. We therefore suggest that the oxygen isotope anomaly of nitrate from January (high MED) to July (low MED) is the result of tropospheric $\mathrm{NO}_{\mathrm{x}}$ chemistry, as modeled by Michalski et al. (2003) and suggested by Hastings et al. $(2003,2004)$ and this results could be a powerful technique to constrain oxidant fields in this part of the world. This indicates that the winter source of nitrate is most presumably oxidation of tropospheric background $\mathrm{NO}_{\mathrm{x}}$, probably generated by organic nitrates (PAN + alkyl nitrate), en route to Antarctica.

\subsubsection{Period 3}

In the Antarctic, unlike the Arctic, stratospheric denitrification is accompanied by a simultaneous dehydration in late winter (Fahey et al., 1990; Santee et al., 1995). As PSCs penetrate the troposphere they evaporate and liberate both ${ }^{3} \mathrm{HHO}$ vapor and $\mathrm{HNO}_{3}$ gas. This period is characterized by a small but significant enhancement of particulate nitrate concentration, in phase with ${ }^{3} \mathrm{H}$ activity of the snow found in the coastal site of Halley Bay (Fig. 1a), strongly suggesting the stratosphere as the source for the $\mathrm{p}-\mathrm{NO}_{3}^{-}$peak during $\mathrm{Pe}$ riod 3. This interpretation is further supported by the oxygen isotope anomalies during this period. At this period of the year, $\Delta{ }^{17} \mathrm{O}$ peaks at values only observed in the Antarctic atmosphere. Using the most extreme ozone isotope anomalies and the upper limit of the transfer coefficient, we can explain the nitrate oxygen isotope anomalies. Considering that stratospheric ozone generally possesses a higher oxygen anomaly than tropospheric ozone, we suggest that $\Delta^{17} \mathrm{O}$ peak represents a further argument in the direction of a stratospheric origin for the nitrate of period 3. At this stage, however, there are too many unknowns to go beyond these qualitative arguments, especially in absence of better constrains of the isotope anomaly transfer between $\mathrm{O}_{3} / \mathrm{NO}_{\mathrm{x}} / \mathrm{NO}_{\mathrm{y}}$ species.

Because of the overlap between nitrogen isotopic composition of stratospheric and tropospheric-produced nitrate, ${ }^{15} \mathrm{~N}$ signatures of the period 3 do not contribute to additional evidence, but are compatible with a stratospheric origin.

Flux calculations performed previously (Sect. 4.1.1) do not contradict this suggestion. We estimated the additional concentration per day to be around (32.5 \pm 13.4$) \mathrm{ng} \mathrm{m}^{-3} \mathrm{~d}^{-1}$. At first glance, this value seems to overestimate the observed increase in atmospheric concentration during Period 3 relatively to the Period 4 concentration increase. However, it should be borne in mind that part of this stratospheric nitrate will be transported outside Antarctica and some others will be stored temporarily and/or permanently in snow. Measurements suggest that the Antarctic plateau receives 2.4 $5.7 \mathrm{~kg} \mathrm{~N} \mathrm{~km}^{-2} \mathrm{a}^{-1}$ from denitrification (Muscari et al., 2003) among which $2.1 \mathrm{~kg} \mathrm{~N} \mathrm{~km}^{-2} \mathrm{a}^{-1}$ are buried as nitrate, based on ice core analysis (Legrand and Kirchner, 1990). Meteorology of PSC above DDU supports the hypothesis of a stratospheric source for the late winter concentration peak.

\subsubsection{Period 4}

Considering the arguments developed above, we propose that the November/December nitrate peak is not the direct result of PSC subsidence as suggested by Wagenbach et al. (1998). The most striking feature of the $\delta^{15} \mathrm{~N}$ time series are the negative values observed during period 4 (Fig. 1b). Such low values are in remarkable contrast with the tropospheric range and call for a distinctive process peculiar to Antarctica, since no other parts of the world show such a depletion (Heaton et al., 2004). Estimation of the nitrogen isotopic 
composition of reemitted $\mathrm{NO}_{\mathrm{y}}$ from the snow strongly suggests that snow emission is responsible for the late spring concentration peak. We are not aware of any other source capable of producing such low ${ }^{15} \mathrm{~N}$ isotopic ratios, especially in the atmosphere. This suggestion has the advantage to eliminate the time lag that was persisting between ${ }^{3} \mathrm{H}$ and PSC nitrate in Wagenbach et al. (1998), a failing already mentioned and unexplained by these authors.

Oxygen isotope anomalies during this period are compatible with snow emissions if one assumes an equal mixture of snow-emitted $\mathrm{HNO}_{3}$ and snow-emitted $\mathrm{NO}_{\mathrm{x}}$, the former having the mean annual oxygen isotopic signature of inland snow, the latter acquiring a tropospheric signature during transport from inland to the coast. This suggestion offers a possible explanation for the offset observed in Fig. 6, with summertime nitrate still possessing a fraction with a stratospheric-type oxygen isotopic composition.

Inland drift of air masses is symptomatic of the DDU wind field. Our estimate of $\mathrm{NO}_{\mathrm{y}}$ fluxes from the snow supports our conclusion, based on concentration profiles observed at different low accumulation sites.

\section{Summary and conclusions}

Year-round aerosol collections of inorganic particulate nitrate have been analyzed for their isotopic content. This study constitutes the first oxygen and nitrogen isotopic survey of atmospheric nitrate in coastal Antarctica. Using the bacterial denitrifier technique in combination with a novel $\mathrm{N}_{2} \mathrm{O}$ decomposition method, the $\delta^{18} \mathrm{O}, \Delta^{17} \mathrm{O}$ and $\delta^{15} \mathrm{~N}$ have been precisely measured on small samples. Size-segregated analyses show no fundamental differences in the seasonal variation between particle size fractions below and above $1 \mu \mathrm{m}$, even if significant differences exist for individual samples. In the absence of multiple year analysis, we have ignored these differences and decided to treat only the mass and isotopic weighted average signal. Applying current knowledge on the origin of the ozone oxygen isotope anomaly $\left(\Delta^{17} \mathrm{O}\right)$ and the ${ }^{15} \mathrm{~N}$ fractionation constants in the stratosphere and snow, we consider we have established the main isotopic characteristics of tropospheric, stratospheric, and snow reservoirs of nitrate at least semi-quantitatively. A comparison between our isotopic dataset and the isotopic signature of these sources suggests the following scenario:

1. The precise source of background concentrations of atmospheric nitrate is not identifiable. However, the $\delta^{18} \mathrm{O}$ and $\Delta^{17} \mathrm{O}$ of background atmospheric nitrate are compatible with nitrate formed predominantly in the troposphere, with isotopic variations being explained by sunlight-driven changes in the mechanism of $\mathrm{NO}_{\mathrm{x}}$ oxidation to $\mathrm{HNO}_{3}$.

2. Estimates of the stratospheric isotopic composition of nitrate revealed that the secondary peak around August-
September is most likely associated with polar stratospheric cloud subsidence.

3. Snow reemissions of $\mathrm{NO}_{\mathrm{x}}$ and nitric acid from the interior of the Antarctic continent seem to be the principal cause of the major late spring peak. Only this source has all the characteristics necessary to generate atmospheric nitrate that is highly depleted in ${ }^{15} \mathrm{~N}$.

Our new scenario, backed up by mass balance calculations, reconciles the expected simultaneity between the tritium maximum and a nitrate concentration maximum if both derive from stratospheric sources. Furthermore, it suggests a higher oxygen isotope anomaly of stratospheric nitrate compared to tropospheric nitrate. However, we also pointed out the weakness and current limitations of isotopic studies in the absence of a better quantification and understanding of the anomalous oxygen transfer from reactants to products. As further directions of research, we can list (not in order of priority):

1. The internal isotopic distribution of ozone isotopomers (Tuzson, 2005),

2. The reaction mechanism between $\mathrm{O}_{3}$ and reactive species (with halogen for instance) and more generally the photochemical equilibrium between $\mathrm{O}_{3}$ and $\mathrm{NO}_{\mathrm{x}}$,

3. A comprehensive transport/chemistry model adapted to polar chemistry to establish the main oxidation pathways leading to nitrate formation,

4. Measurements of the spatial and temporal variations of the isotopic composition of nitrate in air and snow,

5. Measurements of the stratospheric ozone isotopic composition inside the polar vortex,

6. Measurements of the isotopic composition of nitric acid found in PSCs.

In summary, the dynamics of atmospheric inorganic nitrate in coastal Antarctic boundary layer can be described by a stable tropospheric background source with the stratosphere injecting large amounts of nitrate via polar stratospheric clouds denitrification in late winter, with the majority of it captured and trapped in the snow until the thermodynamical conditions of spring/summer times allow for its release from this buffered reservoir. Such a scenario could be further tested as follows: late winter in the Antarctic plateau should be characterized by a high concentration of gaseous nitric acid. Data to test this prediction are not currently available. We want to emphasize that particulate nitrate measurements will not be a suitable measurement to reveal such seasonal features in inland sites. Nitric acid has a high affinity to alkaline aerosols, therefore revealing more the seasonality of aerosols than the 
nitric acid concentration variability. We expect other tropospheric trace gases to be also influenced by snowpack emissions in summer on coastal sites, a phenomenon already observed for formaldehyde $(\mathrm{HCOOH})$ and hydrogen peroxide $\left(\mathrm{H}_{2} \mathrm{O}_{2}\right)$ (Frey et al., 2005; Riedel et al., 2005).

\section{Appendix A}

\section{Estimation of nitrogen isotopic composition of polar stratospheric nitrate}

The ${ }^{15} \mathrm{~N} /{ }^{14} \mathrm{~N}$ ratio of stratospheric $\mathrm{N}_{2} \mathrm{O}$ can be described empirically by a Rayleigh fractionation equation (Rahn and Wahlen, 1997; Kaiser et al., 2002a, 2006; Toyoda et al., 2004):

$\ln \frac{\delta^{15} \mathrm{~N}\left(\mathrm{~N}_{2} \mathrm{O}\right)+1}{\delta^{15} \mathrm{~N}\left(\mathrm{~N}_{2} \mathrm{O}\right)_{0}+1}={ }^{15} \varepsilon_{\text {sinks }} \ln \frac{\mu\left(\mathrm{N}_{2} \mathrm{O}\right)}{\mu\left(\mathrm{N}_{2} \mathrm{O}\right)_{0}}$

where $\delta$ and $\mu\left(\mathrm{N}_{2} \mathrm{O}\right)$ are the isotopologue ratio and mixing ratios of $\mathrm{N}_{2} \mathrm{O}$, respectively, with the subscript " 0 " referring to the initial value before decomposition (i.e. in the troposphere). $\varepsilon_{\text {sinks }}{ }^{2}$ is the apparent fractionation constant between $\mathrm{N}_{2} \mathrm{O}$ and the overall destruction processes, which is related to the overall rate constant of the decomposition reaction involving heavy $\left(\mathrm{k}_{h}\right)$ and light $\left(\mathrm{k}_{l}\right) \mathrm{N}_{2} \mathrm{O}$ isotopologues and binds the isotopic composition of $\mathrm{N}_{2} \mathrm{O}$ and the products:

${ }^{15} \varepsilon_{\text {sinks }}=\frac{k_{h}}{k_{l}}-1=\frac{\delta^{15} \mathrm{~N}(\text { products })-\delta^{15} \mathrm{~N}\left(\mathrm{~N}_{2} \mathrm{O}\right)}{1+\delta^{15} \mathrm{~N}\left(\mathrm{~N}_{2} \mathrm{O}\right)}$

Isotopic fractionation of $\mathrm{N}_{2} \mathrm{O}$ during photo-dissociation and oxidation-reduction have been studied intensively (Johnston et al., 1995; Rahn and Wahlen, 1997; Miller and Yung, 2000; Röckmann et al., 2000; Zhang et al., 2000; Kaiser et al., 2002b, 2003b), and these studies yielded a high quality dataset to estimate the ${ }^{15} \mathrm{~N}$ composition of the $\mathrm{N}_{2} \mathrm{O}$ decomposition products.

For Reaction (R1), the process controlling the $\mathrm{N}_{2} \mathrm{O}$ concentration, but exerting no impact on stratospheric NO isotopic composition, laboratory experiments give a range of ${ }^{15} \varepsilon_{R 1}$ between $-48.5 \%$ and $-34.8 \%$ at $233 \mathrm{~K}$ (Röckmann et al., 2001; Kaiser et al., 2002b; Toyoda et al., 2004). Kaiser et al. (2002a) showed that the isotopic fractionation constant for Reaction (R2) reactions is ${ }^{15} \varepsilon_{\mathrm{R} 2}=k\left({ }^{15} \mathrm{~N}^{14} \mathrm{NO}\right) / k\left({ }^{14} \mathrm{~N}_{2} \mathrm{O}\right)$ $1=-5.5 \%$, and is insensitive to temperature and pressure. Reaction (R2a) is the main source of $\mathrm{NO}_{\mathrm{y}}$ in the stratosphere and explains the correlation observed between $\mathrm{NO}_{\mathrm{y}}$ and $\mathrm{N}_{2} \mathrm{O}$ concentration in the stratosphere (Muscari et al., 2003). Therefore, only this branch (Reaction R2a) needs to

\footnotetext{
${ }^{2}$ The definition of fractionation constant we adopted here is the one commonly used in geochemistry, i.e. the definition using the ratio of the heavy isotope over the light isotope $(\varepsilon)$. For publications using the inverse ratio $\left(\varepsilon^{\prime}\right)$, we use the relation $\varepsilon=\left(-\varepsilon^{\prime}\right) /\left(\varepsilon^{\prime}+1\right)$ to recalculate the fractionation constant according to our definition.
}

be considered here to estimate the ${ }^{15} \mathrm{~N} /{ }^{14} \mathrm{~N}$ of stratospheric $\mathrm{NO}_{\mathrm{y}}$. Based on transition state theory, Kaiser et al. (2002a) have estimated, the isotopic fractionation constant of the Reaction (R2a) exit channels. This reaction is characterized by $\mathrm{a}^{15} \varepsilon_{\mathrm{R} 2 \mathrm{a}}$ of $-8.1 \%$. Rearranging equation Eq. (A2), and applying it to Reaction (R2a) gives:

$$
\begin{aligned}
\delta^{15} \mathrm{~N}(\mathrm{NO}) & =\delta^{15} \mathrm{~N}\left(\mathrm{~N}_{2} \mathrm{O}\right)\left(1+{ }^{15} \varepsilon_{\mathrm{R} 2 \mathrm{a}}\right)+{ }^{15} \varepsilon_{\mathrm{R} 2 \mathrm{a}} \\
& \approx \delta^{15} \mathrm{~N}\left(\mathrm{~N}_{2} \mathrm{O}\right)+{ }^{15} \varepsilon_{\mathrm{R} 2 \mathrm{a}}
\end{aligned}
$$

Since $\left|{ }^{15} \varepsilon_{\mathrm{R} 2 \mathrm{a}}\right|$ is small compared to $\left|{ }^{15} \varepsilon_{\mathrm{R} 1}\right|$ and since Reaction (R2a) represents only 6 to $9 \%$ of the total $\mathrm{N}_{2} \mathrm{O}$ sinks (Fahey et al., 1990; Muscari et al., 2003), $\delta^{15} \mathrm{~N}\left(\mathrm{~N}_{2} \mathrm{O}\right)$ in the stratosphere is mainly controlled by Reaction (R1) and not by Reaction (R2a). From Eq. (A3), it appears that the isotopic composition of $\mathrm{NO}$ in the stratosphere closely parallels $\mathrm{N}_{2} \mathrm{O}$ nitrogen isotopic profile for all $\delta^{15} \mathrm{~N}\left(\mathrm{~N}_{2} \mathrm{O}\right)$ observed but shifted by $-8.1 \%$. Combining Eq. (A1) and Eq. (A3), an analytic expression for $\delta^{15} \mathrm{~N}(\mathrm{NO})$ as a function of fractionation constants and $\mathrm{N}_{2} \mathrm{O}$ mixing ratio is obtained:

$$
\frac{\delta^{15} \mathrm{~N}(\mathrm{NO})+1}{\delta^{15} \mathrm{~N}\left(\mathrm{~N}_{2} \mathrm{O}\right)_{0}+1}=\left(1+{ }^{15} \varepsilon_{\mathrm{R} 2 \mathrm{a}}\right)\left(\frac{\mu\left(\mathrm{N}_{2} \mathrm{O}\right)}{\mu\left(\mathrm{N}_{2} \mathrm{O}_{0}\right.}\right)^{15} \varepsilon_{\text {sinks }}
$$

Defining $f=\mu\left(\mathrm{N}_{2} \mathrm{O}\right) / \mu\left(\mathrm{N}_{2} \mathrm{O}\right)_{0}$, the isotopic composition of accumulated $\mathrm{NO}$ for any given $f$ (i.e. altitude or $\mathrm{N}_{2} \mathrm{O}$ mixing ratio) is obtained by integrating Eq. (A4):

$$
\frac{\overline{\delta^{15} \mathrm{~N}(\mathrm{NO})}+1}{\delta^{15} \mathrm{~N}\left(\mathrm{~N}_{2} \mathrm{O}\right)_{0}+1}=\left(1+{ }^{15} \varepsilon_{\mathrm{R} 2 \mathrm{a}}\right) \frac{\int_{1}^{f} f^{15} \varepsilon_{\text {sinks }} d f}{\int_{1}^{f} d f}
$$

After integration and rearrangement, we have:

$\overline{\delta^{15} \mathrm{~N}(\mathrm{NO})}=\left(1+{ }^{15} \varepsilon_{\mathrm{R} 2 \mathrm{a}}\right) \frac{1+\delta^{15} \mathrm{~N}\left(\mathrm{~N}_{2} \mathrm{O}\right)_{0}}{1+{ }^{15} \varepsilon_{\text {sinks }}} \frac{1-f^{1+{ }^{15} \varepsilon_{\text {sinks }}}}{1-f}-1$

Acknowledgements. We thank the personnel in the field for having taken care of the weekly operations of the HVAS and G. Cane and D. Graham for help in the laboratory. PNCA, Balzan foundation, C. Lorius, European project CRYOSTAT, and CNRS under its PICS program are acknowledged for their financial support of J. Savarino. The French polar institute (IPEV) is thanked for its logistic support. This work has been made possible thanks to the partial support from the European Science Foundation (ESF) under the EUROCORES Programme EuroCLIMATE, through contract No. ERAS-CT-2003-980409 of the European Commission, DG Research, FP6. We are grateful for constructive comments, remarks and advice from the three anonymous referees, A. Tuck and C. Janssen. This work would not have been possible without the support of M. Legrand, S. Preunkert and B. Jourdain.

Edited by: C. A. M. Brenninkmeijer 


\section{References}

Alexander, B., Savarino, J., Kreutz, K., and Thiemens, M. H.: Impact of preindustrial biomass-burning emissions on the oxidative pathways of tropospheric sulfur and nitrogen, J. Geophys. Res., 109, D08303, doi:08310.01029/02003JD004218, 2004.

Angert, A., Rachmilevitch, S., Barkan, E., and Luz, B.: Effects of photorespiration, the cytochrome pathway, and the alternative pathway on the triple isotopic composition of atmospheric $\mathrm{O}_{2}$, Global Biogeochem. Cycles, 17(1), 1030, doi:1010.1029/2002GB001933, 2003.

Assonov, S. S. and Brenninkmeijer, C. A. M.: Reporting small Delta O-17 values: existing definitions and concepts, Rapid Commun. Mass. Spectrom., 19(5), 627-636, 2005.

Barkan, E. and Luz, B.: High-precision measurements of ${ }^{17} \mathrm{O} /{ }^{16} \mathrm{O}$ and ${ }^{18} \mathrm{O} /{ }^{16} \mathrm{O}$ of $\mathrm{O}_{2}$ and $\mathrm{O}_{2} / \mathrm{Ar}$ ratio in air, Rapid Commun. Mass. Spectrom., 17(24), 2809-2814, 2003.

Beine, H. J., Honrath, R. E., Domine, F., Simpson, W. R., and Fuentes, J. D.: $\mathrm{NO}_{x}$ during background and ozone depletion periods at Alert: Fluxes above the snow surface, J. Geophys. Res., 107(D21), 4584, doi:4510.1029/2002JD002082, 2002.

Bigeleisen, J.: The effects of isotopic substitutions on the rates of chemical reactions, J. Phys. Chem., 56, 823-828, 1952.

Blunier, T., Floch, G. L., Jacobi, H.-W., and Quansah, E.: Isotopic view on nitrate loss in Antarctica surface snow, Geophys. Res. Lett., 32, L13501, doi:13510.11029/12005GL023011, 2005.

Brand, W. A.: High precision isotope ratio monitoring techniques in mass spectrometry, J. Mass Spectrom., 31(3), 225-235, 1996.

Brasseur, G. and Solomon, S.: Aeronomy of the middle atmosphere, 452 pp., Reidel, D., Norwell, MA, 1986.

Brenninkmeijer, C. A. M., Janssen, C., Kaiser, J., Röckmann, T., Rhee, T. S., and Assonov, S. S.: Isotope effects in the chemistry of atmospheric trace compounds, Chem. Rev., 103(12), 51255161, 2003.

Burkhart, J. F., Hutterli, M., Bales, R. C., and McConnell, J. R.: Seasonal accumulation timing and preservation of nitrate in firn at Summit, Greenland, J. Geophys. Res., 109, D19302, doi:19310.11029/12004JD004658, 2004.

Burns, D. A. and Kendall, C.: Analysis of delta N-15 and delta O18 to differentiate $\mathrm{NO}_{3}^{-}$sources in runoff at two watersheds in the Catskill Mountains of New York, Water Resour. Res., 38(5), doi:10.1029/2001WR000292, 2002.

Campbell, D. H., Kendall, C., Chang, C. C. Y., Silva, S. R., and Tonnessen, K. A.: Pathways for nitrate release from an alpine watershed: Determination using delta N-15 and delta O-18, Water Resour. Res., 38(4), doi:10.1029/2001WR001578, 2002.

Cantrell, C. A., Shetter, R. E., and Calvert, J. G.: Branching ratios for the $\mathrm{O}\left({ }^{1} \mathrm{D}\right)+\mathrm{N}_{2} \mathrm{O}$ reaction, J. Geophys. Res., 99(D2), 37393743, 1994.

Casciotti, K. L., Sigman, D. M., Galanter Hastings, M., Böhlke, J. K., and Hilkert, A.: Measurement of the oxygen isotopic composition of nitrate in seawater and freshwater using the denitrifier method, Anal. Chem., 74, 4905-4912, 2002.

Cotter, E. S. N., Jones, A. E., Wolff, E. W., and Bauguitte, S. J. B.: What controls photochemical $\mathrm{NO}$ and $\mathrm{NO}_{2}$ production from Antarctic snow? Laboratory investigation assessing the wavelength and temperature dependence, J. Geophys. Res., 108(D4), 4147, doi:10.1029/2002JD002602, 2003.

Davis, D., Nowak, J. B., Chen, G., Buhr, M., Arimoto, R., Hogan, A., Eisele, F., Mauldin, L., Tanner, D., Shetter, R., Lefer, B., and
McMurry, P.: Unexpected high levels of NO observed at South Pole, Geophys. Res. Lett., 28(19), 3625-3628, 2001.

Davis, D. D., Eisele, F., Chen, G., et al.: An overview of ISCAT 2000, Atmos. Environ., 5363-5373, 2004a.

Davis, D., Chen, G., Buhr, M., Crawford, J., Lenschow, D., Lefer B., Shetter, R., Eisele, F., Mauldin, L., and Hogan, A.: South Pole $\mathrm{NO}_{\mathrm{x}}$ chemistry: an assessment of factors controlling variability and absolute levels, Atmos. Environ., 38(32), 5375-5388, 2004b.

de Zafra, R. and Smyshlyaev, S. P.: On the formation of $\mathrm{HNO}_{3}$ in the Antarctic mid to upper stratosphere in winter, J. Geophys. Res., 106(D19), 23 115-23 125, 2001.

Dibb, J. E. and Whitlow, S.: Recent climate anomalie and their impact on snow chemistry at South Pole, 1987-1994, Geophys. Res. Lett., 23(10), 1115-1118, 1996.

Dibb, J. E., Huey, L. G., Slusher, D. L., and Tanner, D. J.: Soluble reactive nitrogen oxides at South Pole during ISCAT 2000, Atmos. Environ., 38(32), 5399-5409, 2004.

Domine, F. and Shepson, P. B.: Air-snow interactions and atmospheric chemistry, Science, 297(5586), 1506-1510, 2002.

Ehhalt, D. H., Rohrer, F., Schauffler, S., and Pollock, W.: Tritiated water vapor in the stratosphere: Vertical profiles and residence time, J. Geophys. Res., 107(D24), 4757, doi:4710.1029/2001JD001343, 2002.

Fahey, D. W., Kelly, K. K., Kawa, S. R., and Tuck, A. F.: Observations of denitrification and dehydration in the winter polar atmosphere, Nature, 344, 321-324, 1990.

Farquhar, J., Savarino, J., Jackson, T. L., and Thiemens, M. H.: Evidence of atmospheric sulfur in the Martian regolith from sulfur isotopes in meteorites, Nature, 404, 50-52, 2000.

Finlayson-Pitts, B. J. and Pitts, J. N.: Chemistry of the upper and lower atmosphere: Theory, experiments and applications, 969 pp., Academic Press, San Diego, CA, 2000

Fogel, M. L. and Paerl, H. W.: Isotopic tracers of nitrogen from atmospheric deposition to coastal waters, Chem. Geol., 107(34), 233-236, 1993.

Frey, M. M., Stewart, R. W., McConnell, J. R., and Bales, R. C.: Atmospheric hydroperoxides in West Antarctica: Links to stratospheric ozone and atmospheric oxidation capacity, J. Geophys. Res., 110(D23), D23301, doi:23310.21029/22005JD006110, 2005.

Freyer, H. D.: Seasonal trends of $\mathrm{NH}_{4}^{+}$and $\mathrm{NO}_{3}^{-}$nitrogen isotope composition in rain at Jülich, Germany, Tellus, 30, 83-92, 1978.

Freyer, H. D.: Seasonal variation of ${ }^{15} \mathrm{~N} /{ }^{14} \mathrm{~N}$ ratios in atmospheric nitrate species, Tellus, 43B, 30-44, 1991.

Freyer, H. D., Kobel, K., Delmas, R. J., Kley, D., and Legrand, M. R.: First results of $\mathrm{N}-15 / \mathrm{N}-14$ ratios in nitrate from alpine and polar ice cores, Tellus, 48B(1), 93-105, 1996.

Funke, B., Lopez-Puertas, M., Gil-Lopez, S., von Clarmann, T., Stiller, G. P., Fischer, H., and Kellmann, S.: Downward transport of upper atmospheric $\mathrm{NO}_{\mathrm{x}}$ into the polar stratosphere and lower mesosphere during the Antarctic 2003 and Arctic 2002/2003 winters, J. Geophys. Res., 110, D24308, doi:24310.21029/22005JD006463, 2005.

Gao, Y. Q. and Marcus, R. A.: Strange and unconventional isotope effects in ozone formation, Science, 293(5528), 259-263, 2001.

Hanson, D. R. and Ravishankara, A. R.: The Reaction Probabilities of $\mathrm{ClONO}_{2}$ and $\mathrm{N}_{2} \mathrm{O}_{5}$ on Polar Stratospheric Cloud Materials, J. Geophys. Res., 96(D3), 5081-5090, 1991. 
Hastings, M. G., Sigman, D. M., and Lipschultz, F.: Isotopic evidence for source changes of nitrate in rain at Bermuda, J. Geophys. Res., 108(D24), 4790, doi:4710.1029/2003JD003789, 2003.

Hastings, M. G., Steig, E. J., and Sigman, D. M.: Seasonal variations in $\mathrm{N}$ and $\mathrm{O}$ isotopes of nitrate in snow at Summit, Greenland: Implications for the study of nitrate in snow and ice cores, J. Geophys. Res., 109, D20306, doi:20310.21029/22004JD004991, 2004.

Hastings, M. G., Sigman, D. M., and Steig, E. J.: Glacial/interglacial changes in the isotopes of nitrate from the Greenland Ice Sheet Project 2 (GISP2) ice core, Global Biogeochem. Cycles, 19, GB4024, doi:4010.1029/2005GB002502, 2005.

Heaton, T. H. E.: ${ }^{15} \mathrm{~N} /{ }^{14} \mathrm{~N}$ ratios of nitrate and ammonium in rain at Pretoria, South Africa, Atmos. Environ., 21(4), 843-852, 1987.

Heaton, T. H. E.: ${ }^{15} \mathrm{~N} /{ }^{14} \mathrm{~N}$ ratios of $\mathrm{NO}_{\mathrm{x}}$ from vehicule engines and coal-fired power stations, Tellus, 42B, 304-307, 1990.

Heaton, T. H. E., Wynn, P., and Tye, A. M.: Low ${ }^{15} \mathrm{~N} /{ }^{14} \mathrm{~N}$ ratios for nitrate in snow in the High Arctic $\left(79^{\circ} \mathrm{N}\right)$, Atmos. Environ., 38(33), 5611-5621, 2004.

Herron, M. M.: Impurity Sources of F-, Cl-, $\mathrm{NO}_{3}^{-}$and $\mathrm{SO}_{4}^{2-}$ in Greenland and Antarctic Precipitation, J. Geophys. Res., 87 (NC4), 3052-3060, 1982.

Hoering, T.: The isotopic composition of the ammonia and the nitrate ion in rain, Geochim. Cosmochim. Acta, 12, 97-102, 1957.

Honrath, R. E., Peterson, M. C., Guo, S., Dibb, J. E., Shepson, P. B., and Campbell, B.: Evidence of $\mathrm{NO}_{x}$ production within or upon ice particles in the Greenland snowpack, Geophys. Res. Lett., 26(6), 695-698, 1999.

Honrath, R. E., Guo, S., Peterson, M. C., Dziobak, M. P., Dibb, J. E., and Arsenault, M. A.: Photochemical production of gas phase $\mathrm{NO}_{\mathrm{x}}$ from ice crystal $\mathrm{NO}_{3}$, J. Geophys. Res., 105(D19), 24 183-24 190, 2000a.

Honrath, R. E., Peterson, M. C., Dziobak, M. P., Dibb, J. E., Arsenault, M. A., and Green, S. A.: Release of NOx from sunlightirradiated midlatitude snow, Geophys. Res. Lett., 27(15), 22372240, 2000b.

Honrath, R. E., Lu, Y., Peterson, M. C., Dibb, J. E., Arsenault, M. A., Cullen, N. J., and Steffen, K.: Vertical fluxes of $\mathrm{NO}_{\mathrm{x}}, \mathrm{HONO}$, and $\mathrm{HNO}_{3}$ above the snowpack at Summit, Greenland, Atmos. Environ., 36(15-16), 2629-2640, 2002.

Irion, F. W., Gunson, M. R., Rinsland, C. P., Yung, Y. L., Abrams, M. C., Chang, A. Y., and Goldman, A.: Heavy ozone enrichments from ATMOS infrared solar spectra, Geophys. Res. Lett., 23(17), 2377-2380, 1996.

Jackman, C. H., Douglass, A. R., Rood, R. B., McPeters, R. D., and Meade, P. E.: Effect of solar proton events on the middle atmosphere during the past 2 solar-cycles as computed Using a 2dimensional model, J. Geophys. Res., 95(D6), 7417-7428, 1990.

Jacobi, H. W., Weller, R., Jones, A. E., Anderson, P. S., and Schrems, O.: Peroxyacetyl nitrate (PAN) concentrations in the Antarctic troposphere measured during the photochemical experiment at Neumayer (PEAN'99), Atmos. Environ., 34(29-30), 5235-5247, 2000.

Janssen, C.: Intramolecular isotope distribution in heavy ozone ((OOO)-O-16-O-18-O-16 and (OOO)O-16-O-16-O-18), J. Geophys. Res., 110, D08308, doi:08310.01029/02004JD005479, 2005.
Johnston, J. C., Cliff, S. S., and Thiemens, M. H.: Measurement of multioxygen isotopic (Delta-O-18 and Delta-O-17) fractionation factors in the stratospheric sink reactions of nitrous-oxide, J. Geophys. Res., 100(D8), 16801-16 804, 1995.

Johnston, J. C. and Thiemens, M. H.: The isotopic composition of tropospheric ozone in three environments, J. Geophys. Res., 102(D21), 25 395-25 404, 1997.

Jones, A. E., Weller, R., Minikin, A., Wolff, E. W., Sturges, W. T., McIntyre, H. P., Leonard, S. R., Schrems, O., and Bauguitte, S.: Oxidized nitrogen chemistry and speciation in the Antarctic troposphere, J. Geophys. Res., 104(D17), 21 355-21 366, 1999.

Jones, A. E., Weller, R., Wolff, E. W., and Jacobi, H. W.: Speciation and rate of photochemical $\mathrm{NO}$ and $\mathrm{NO}_{2}$ production in Antarctic snow, Geophys. Res. Lett., 27(3), 345-348, 2000.

Jones, A. E., Weller, R., Anderson, P. S., Jacobi, H. W., Wolff, E. W., Schrems, O., and Miller, H.: Measurements of $\mathrm{NO}_{\mathrm{x}}$ emissions from the Antarctic snowpack, Geophys. Res. Lett., 28(8), 1499-1502, 2001.

Jones, A. E. and Wolff, E. W.: An analysis of the oxidation potential of the South Pole boundary layer and the influence of stratospheric ozone depletion, J. Geophys. Res., 108(D18), 4565, doi:4510.1029/2003JD003379, 2003.

Jourdain, B. and Legrand, M.: Year-round records of bulk and sizesegregated aerosol composition and $\mathrm{HCl}$ and $\mathrm{HNO}_{3}$ levels in the Dumont d'Urville (coastal Antarctica) atmosphere: Implications for sea-salt aerosol fractionation in the winter and summer, J. Geophys. Res., 107(D22), 4645, doi:4610.1029/2002JD002471, 2002.

Kaiser, J., Brenninkmeijer, C. A. M., and Röckmann, T.: Intramolecular ${ }^{15} \mathrm{~N}$ and ${ }^{18} \mathrm{O}$ fractionation in the reaction of $\mathrm{N}_{2} \mathrm{O}$ with $\mathrm{O}\left({ }^{1} \mathrm{D}\right)$ and its implications for the stratospheric $\mathrm{N}_{2} \mathrm{O}$ isotope signature, J. Geophys. Res., 107, 4214, doi:4210.1029/2001JD001506, 2002a.

Kaiser, J., Röckmann, T., and Brenninkmeijer, C. A. M.: Temperature dependence of isotope fractionation in $\mathrm{N}_{2} \mathrm{O}$ photolysis, Phys. Chem. Chem. Phys., 4, 4420-4430, 2002b.

Kaiser, J., Rockmann, T., and Brenninkmeijer, C. A. M.: Complete and accurate mass spectrometric isotope analysis of tropospheric nitrous oxide, J. Geophys. Res., 108(D15), 4476, doi:4410.1029/2003JD003613, 2003a.

Kaiser, J., Roeckmann, T., Brenninkmeijer, C. A. M., and Crutzen, P. J.: Wavelength dependence of isotope fractionation in $\mathrm{N}_{2} \mathrm{O}$ photolysis, Atmos. Chem. Phys., 3(2), 303-313, 2003b.

Kaiser, J., Rockmann, T., and Brenninkmeijer, C. A. M.: Contribution of mass-dependent fractionation to the oxygen isotope anomaly of atmospheric nitrous oxide, J. Geophys. Res., 109, D03305, doi:03310.01029/02003JD004088, 2004.

Kaiser, J., Engel, A., Borchers, R., and Röckmann, T.: Probing stratospheric transport and chemistry with new balloon and aircraft observations of the meridional and vertical $\mathrm{N}_{2} \mathrm{O}$ isotope distribution, Atmos. Chem. Phys., 6, 4273-4324, 2006,

http://www.atmos-chem-phys.net/6/4273/2006/.

Kaiser, J., Hastings, M. G., Houlton, B. Z., Röckmann, T., and Sigman, D. M.: Triple oxygen isotope analysis of nitrate using the denitrifier method and thermal decomposition of $\mathrm{N}_{2} \mathrm{O}$, Anal. Chem., 79(2), 599-607, 2007.

Kendall, C.: Tracing Nitrogen Sources and Cycling in Catchments., in: Tracers in Catchment Hydrology, edited by: Kendall, C. and McDonnell, J. J., pp. 519-576, Elsevier Science, Amsterdam, 
1998.

Kerher, K., Johnson, P. V., Wood, S. W., Nardi, B., and Platt, U.: Ground-based measurements of tropospheric and stratospheric BrO at Arrivals Heights, Antarctica, Geophys. Res. Lett., 24(23), 3021-3024, 1997.

Koba, K., Tokuchi, N., Wada, E., Nakajima, T., and Iwatsubo, G.: Intermittent denitrification: The application of a N-15 natural abundance method to a forested ecosystem, Geochim. Cosmochim. Acta, 61(23), 5043-5050, 1997.

König-Langlo, G., King, J. C., and Pettre, P.: Climatology of the three coastal Antarctic stations Dumont d'Urville, Neumayer, and Halley, J. Geophys. Res., 103(D9), 10 935-10 946, 1998.

Krankowsky, D., Bartecki, F., Klees, G. G., Mauersberger, K., Schellenbach, K., and Stehr, J.: Measurement of heavy isotope enrichment in tropospheric ozone, Geophys. Res. Lett., 22(13), 1713-1716, 1995.

Krankowsky, D., Lammerzahl, P., and Mauersberger, E.: Isotopic measurements of stratospheric ozone, Geophys. Res. Lett., 27(17), 2593-2595, 2000.

Lämmerzahl, P., Röckmann, T., Brenninkmeijer, C. A. M., Krankowsky, D., and Mauersberger, K.: Oxygen isotope composition of stratospheric carbon dioxide, Geophys. Res. Lett., 29(12), 1582, doi:1510.1029/2001GL014343, 2002.

Legrand, M., Ducroz, F., Wagenbach, D., Mulvaney, R., and Hall, J.: Ammonium in coastal Antarctic aerosol and snow: Role of polar ocean and penguin emissions, J. Geophys. Res., 103(D9), 11 043-11 056, 1998.

Legrand, M. R. and Delmas, R. J.: Relative contributions of tropospheric and stratospheric sources to nitrate in Antarctic snow, Tellus, 38B(3-4), 236-249, 1986.

Legrand, M. R. and Kirchner, S.: Origins and variations of nitrate in south polar precipitation, J. Geophys. Res., 95(D4), 3493-3507, 1990.

Lyons, J. R.: Mass-independent fractionation of oxygen-containing radicals in the atmosphere, Geophys. Res. Lett., 28(17), 32313234, 2001.

Mariotti, A.: Atmospheric nitrogen is a reliable standard for natural N-15 abundance measurements, Nature, 303(5919), 685-687, 1983.

Mariotti, A.: Natural N-15 abundance measurements and atmospheric nitrogen standard calibration, Nature, 311(5983), 251$252,1984$.

Matsuhisa, Y., Goldsmith, J. R., and Clayton, R. N.: Mechanisms of hydrothermal crystallization of quartz, Geochim. Cosmochim. Acta, 42, 173-182, 1978.

Mauersberger, K., Lammerzahl, P., and Krankowsky, D.: Stratospheric ozone isotope enrichments - revisited, Geophys. Res. Lett., 28(16), 3155-3158, 2001.

Mayewski, P. A., Lyons, W. B., Spencer, M. J., Twickler, M. S., Buck, C. F., and Whitlow, S.: An ice-core record of atmospheric response to anthropogenic sulphate and nitrate, Nature, 346(6284), 554-556, 1990.

Mayewski, P. A. and Legrand, M. R.: Recent increase in nitrate concentration of antarctic snow, Nature, 346(6281), 258-260, 1990.

McCabe, J., Savarino, J., and Thiemens, M. H.: Isotopic analysis of nitrate in South Pole snow and air, EOS Trans. AGU, 86(52), Fall Meet. Suppl., abstract A13F-04, 2005a.

McCabe, J. R., Boxe, C. S., Colussi, A. J., Hoffman, M. R., and Thiemens, M. H.: Oxygen isotopic fractionation in the photo- chemistry of nitrate in water and ice, J. Geophys. Res., 110, D15310, doi:15310.11029/12004JD005484, 2005b.

McCracken, K. G., Dreschhoff, G. A. M., Smart, D. F., and Shea, M. A.: Solar cosmic ray events for the period 1561-1994 2. The Gleissberg periodicity, J. Geophys. Res., 106(A10), 21599 $21609,2001$.

Michalski, G., Scott, Z., Kabiling, M., and Thiemens, M. H.: First measurements and modeling of $\Delta^{17} \mathrm{O}$ in atmospheric nitrate, Geophys. Res. Lett., 30(16), 1870, doi:1810.1129/2003GL017015, 2003.

Michalski, G., Bohlke, J. K., and Thiemens, M.: Long term atmospheric deposition as the source of nitrate and other salts in the Atacama Desert, Chile: New evidence from mass-independent oxygen isotopic compositions, Geochim. Cosmochim. Acta, 68(20), 4023-4038, 2004a.

Michalski, G., Meixner, T., Fenn, M., Hernandez, L., Sirulnik, A., Allen, E., and Thiemens, M.: Tracing atmospheric nitrate deposition in a complex semiarid ecosystem using Delta(17)0, Environ. Sci. Technol., 38(7), 2175-2181, 2004b.

Michalski, G., Bockheim, J. G., Kendall, C., and Thiemens, M.: Isotopic composition of Antarctic Dry Valley nitrate: Implications for $\mathrm{NO}_{\mathrm{y}}$ sources and cycling in Antarctica, Geophys. Res. Lett., 32(13), L13817, doi:13810.11029/12004GL022121, 2005.

Miller, C. E. and Yung, Y. L.: Photo-induced isotopic fractionation, J. Geophys. Res., 105(D23), 29 039-29 051, 2000.

Miller, M. F.: Isotopic fractionation and the quantification of O-17 anomalies in the oxygen three-isotope system: an appraisal and geochemical significance, Geochim. Cosmochim. Acta, 66(11), 1881-1889, 2002.

Minschwaner, K., Salawitch, R. J., and McElroy, M. B.: Absorption of solar radiation by $\mathrm{O}_{2}$ : Implications for $\mathrm{O}_{3}$ and lifetimes of $\mathrm{N}_{2} \mathrm{O}, \mathrm{CFCl}_{3}$, and $\mathrm{CF}_{2} \mathrm{Cl}_{2}$, J. Geophys. Res., 98(D6), 10543 $10561,1993$.

Monks, P. S.: Gas-phase radical chemistry in the troposphere, Chem. Soc. Rev., 34(4), 376-395, 2005.

Moore, H.: Isotopic measurement of atmospheric nitrogencompounds, Tellus, 26(1-2), 169-174, 1974.

Moore, H.: The isotopic composition of ammonia, nitrogen dioxide and nitrate in the atmosphere, Atmos. Environ., 11, 1239-1243, 1977.

Morin, S., Savarino, J., Bekki, S., Gong, S., and Bottenheim, J. W.: Signature of Arctic surface ozone depletion events in the isotope anomaly $\left(\Delta^{17} \mathrm{O}\right)$ of atmospheric nitrate, Atmos. Chem. Phys., 7, 1451-1469, 2007, http://www.atmos-chem-phys.net/7/1451/2007/.

Mulvaney, R., Wagenbach, D., and Wolff, E. W.: Postdepositional change in snowpack nitrate from observation of year-round nearsurface snow in coastal Antarctica, J. Geophys. Res., 103(D9), $11021-11031,1998$.

Muscari, G., de Zafra, R. L., and Smyshlyaev, S.: Evolution of the $\mathrm{NO}_{y}-\mathrm{N}_{2} \mathrm{O}$ correlation in the Antarctic stratosphere during 1993 and 1995, J. Geophys. Res., 108(D14), 4428, doi:4410.1029/2002JD002871, 2003.

Nakamura, K., Nakawo, M., Ageta, Y., Goto-Azuma, K., and Kamiyama, K.: Post-depositional loss of nitrate in surface snow layers of the Antarctic ice sheet, Bull. Glaciol. Res., 17, 11-16, 2000.

Neubauer, J. and Heumann, K. G.: Determination of nitrate at the ng/g level in Antarctic snow samples with Ion chromatography 
and isotope-dilution mass-spectrometry, Fresenius Zeitschrift Fur Analytische Chemie, 170-173, 1988.

Orsolini, Y. J., Manney, G. L., Santee, M. L., and Randall, C. E.: An upper stratospheric layer of enhanced $\mathrm{HNO}_{3}$ following exceptional solar storms, Geophys. Res. Lett., 32, L12S01, doi:10.1029/2004GL021588, 2005.

Palmer, A. S., van Ommen, T. V., Curran, M. A. J., and Morgan, V.: Ice-core evidence for a small solar-source of atmospheric nitrate, Geophys. Res. Lett., 28(10), 1953-1956, 2001.

Pichlmayer, F., Schoner, W., Seibert, P., Stichler, W., and Wagenbach, D.: Stable isotope analysis for characterization of pollutants at high elevation alpine sites, Atmos. Environ., 32(23), 4075-4085, 1998.

Preunkert, S., Legrand, M., and Wagenbach, D.: Sulfate trends in a Col du Dome (French Alps) ice core: A record of anthropogenic sulfate levels in the European midtroposphere over the twentieth century, J. Geophys. Res., 106, 31 991-32 004, 2001.

Rahn, T. and Wahlen, M.: Stable isotope enrichment in stratospheric nitrous oxide, Science, 278, 1776-1778, 1997.

Rankin, A. M. and Wolff, E. W.: A year-long record of sizesegregated aerosol composition at Halley, Antarctica, J. Geophys. Res., 108(D24), 4775, doi:4710.1029/2003JD003993, 2003.

Richter, A., Wittrock, F., Ladtsätter-Weissenmayer, A., and Burrows, J. P.: GOME measurements of stratospheric and tropospheric BrO, Adv. Space Res., 29(11), 1667-1672, 2002.

Riedel, K., Allan, W., Weller, R., and Schrems, O.: Discrepancies between formaldehyde measurements and methane oxidation model predictions in the Antarctic troposphere: An assessment of other possible formaldehyde sources, J. Geophys. Res., 110(D15), D15308, doi:15310.11029/12005JD005859, 2005.

Röckmann, T., Brenninkmeijer, C. A. M., Wollenhaupt, M., Crowley, J. N., and Crutzen, P. J.: Measurement of the isotopic fractionation of ${ }^{15} \mathrm{~N}^{14} \mathrm{~N}^{16} \mathrm{O},{ }^{14} \mathrm{~N}^{15} \mathrm{~N}^{16} \mathrm{O}$ and ${ }^{14} \mathrm{~N}^{14} \mathrm{~N}^{18} \mathrm{O}$ in the UV photolysis of nitrous oxide, Geophys. Res. Lett., 27(9), 13991402, 2000.

Röckmann, T., Kaiser, J., Brenninkmeijer, C. A. M., Crowley, J. N., Borchers, R., Brand, W. A., and Crutzen, P. J.: Isotopic enrichment of nitrous oxide $\left({ }^{15} \mathrm{~N}^{14} \mathrm{NO}\right),\left({ }^{14} \mathrm{~N}^{15} \mathrm{NO}\right),\left({ }^{14} \mathrm{~N}^{14} \mathrm{~N}^{18} \mathrm{O}\right)$ in the stratosphere and in the laboratory, J. Geophys. Res., 106(D10), 10 403-10410, 2001.

Röckmann, T. and Levin, I.: High-precision determination of the changing isotopic composition of atmospheric $\mathrm{N}_{2} \mathrm{O}$ from 1990 to 2002, J. Geophys. Res., 110, D21304, doi:21310.21029/22005JD006066, 2005.

Röthlisberger, R., Hutterli, M. A., Sommer, S., Wolff, E. W., and Mulvaney, R.: Factors controlling nitrate in ice cores: Evidence from the Dome C deep ice core, J. Geophys. Res., 105(D16), 20 565-20 572, 2000.

Röthlisberger, R., Hutterli, M. A., Wolff, E. W., Mulvaney, R., Fischer, H., Bigler, M., Goto-Azuma, K., Hansson, M. E., Ruth, U., Siggaard-Andersen, M. L., and Steffensen, J. P.: Nitrate in Greenland and Antarctic ice cores: a detailed description of postdepositional processes, Ann. Glaciol., 35, 209-216, 2002.

Russel, K. M., Galloway, J. N., Macko, S. A., Moody, J. L., and Scudlark, J. R.: Sources of nitrogen in wet deposition to the Chesapeake bay region, Atmos. Environ., 32(14/15), 2453-2465, 1998.

Sander, S. P., Friedl, R. R., DeMore, W. B., Ravishankara, A. R.,
Golden, D. M., Kolb, C. E., Kurylo, M. J., Hampson, R. F., Huie, R. E., Molina, M. J., and Moortgat, G. K.: Chemical kinetics and photochemical data for use in stratospheric modeling, supplement to evaluation 12: Update of key reactions, JPL Publication 00-003, Evaluation number 13, 2000.

Sander, S. P., Ravishankara, A. R., Golden, D. M., Kolb, C. E., Kurylo, M. J., Molina, M. J., Finlayson-Pitts, B. J., and Moortgat, G. K.: Chemical kinetics and photochemical data for use in atmospheric studies, JPL Publication 02-25, Evaluation number 14, 2003.

Santacesaria, V., MacKenzie, A. R., and Stefanutti, L.: A climatological study of polar stratospheric clouds (1989-1997) from LIDAR measurements over Dumont d'Urville (Antarctica), Tellus, 53B(3), 306-321, 2001.

Santee, M. L., Read, W. G., Waters, J. W., Froidevaux, L., Manney, G. L., Flower, D. A., Jarnot, R. F., Harwood, R. S., and Peckham, G. E.: Interhemispheric differences in polar stratospheric $\mathrm{HNO}_{3}$, $\mathrm{H}_{2} \mathrm{O}, \mathrm{ClO}$, and $\mathrm{O}_{3}$, Science, 267(5199), 849-852, 1995.

Santee, M. L., Manney, G. L., Livesey, N. J., and Read, W. G.: Three-dimensional structure and evolution of stratospheric $\mathrm{HNO}_{3}$ based on UARS Microwave Limb Sounder measurements, J. Geophys. Res., 109, D15306, doi:15310.11029/12004JD004578, 2004.

Schaap, M., Muller, K., and ten Brink, H. M.: Constructing the European aerosol nitrate concentration field from quality analysed data, Atmos. Environ., 36(8), 1323-1335, 2002.

Shallcross, D. E., Biggs, P., CanosaMas, C. E., Clemitshaw, K. C., Harrison, M. G., Alanon, M. R. L., Pyle, J. A., Vipond, A., and Wayne, R. P.: Rate constants for the reaction between $\mathrm{OH}$ and $\mathrm{CH}_{3} \mathrm{ONO}_{2}$ and $\mathrm{C}_{2} \mathrm{H}_{5} \mathrm{ONO}_{2}$ over a range of pressure and temperature, J. Chem. Soc. Faraday Trans., 93(16), 2807-2811, 1997.

Sigman, D. M., Casciotti, K. L., Andreani, M., Barford, C., Galanter, M., and Böhlke, J. K.: A bacterial method for the nitrogen isotopic analysis of nitrate in seawater and freshwater, Anal. Chem., 73, 4145-4153, 2001.

Stiller, G. P., Tsidu, G. M., von Clarmann, T., Glatthor, N., Hopfner, M., Kellmann, S., Linden, A., Ruhnke, R., Fischer, H., Lopez-Puertas, M., Funke, B., and Gil-Lopez, S.: An enhanced $\mathrm{HNO}_{3}$ second maximum in the Antarctic midwinter upper stratosphere 2003, J. Geophys. Res., 110, D20303, doi:20310.21029/22005JD006011, 2005.

Talukdar, R. K., Burkholder, J. B., Hunter, M., Gilles, M. K., Roberts, J. M., and Ravishankara, A. R.: Atmospheric fate of several alkyl nitrates .2. UV absorption cross-sections and photodissociation quantum yields, J. Chem. Soc. Faraday Trans., 93(16), 2797-2805, 1997.

Thiemens, M. H. and Heidenreich III, J. E.: The Mass-independent fractionation of oxygen: A novel isotope effect and its possible cosmochemical implications, Science, 219, 1073-1075, 1983.

Thiemens, M. H.: Mass-independent isotope effects in planetary atmospheres and the solar system, Science, 283, 341-345, 1999.

Thiemens, M. H., Savarino, J., Bao, H., and Farquhar, J.: Mass independent isotope compositions in terrestrial and extraterrestrial solids and their applications, Acc. Chem. Res., 34(8), 645-652, 2001.

Toohey, D. W., Brune, W. H., and Anderson, J. G.: Rate-Constant for the Reaction $\mathrm{Br}+\mathrm{O}_{3} \rightarrow \mathrm{BrO}+\mathrm{O}_{2}$ from $248 \mathrm{~K}$ to $418 \mathrm{~K}-$ Kinetics and Mechanism, Int. J. Chem. Kinet., 20(2), 131-144, 1988. 
Toyoda, S., Yoshida, N., Urabe, T., Nakayama, Y., Suzuki, T., Tsuji, K., Shibuya, K., Aoki, S., Nakazawa, T., Ishidoya, S., Ishijima, K., Sugawara, S., Machida, T., Hashida, G., Morimoto, S., and Honda, H.: Temporal and latitudinal distributions of stratospheric $\mathrm{N}_{2} \mathrm{O}$ isotopomers, J. Geophys. Res., 109, D08308, doi:08310.01029/02003JD004316, 2004.

Tuzson, B.: Symmetry specific study of ozone isotopomer formation, PhD-Thesis thesis, Ruprecht-Karls Universität, Heidelberg, 2005.

Udisti, R., Becagli, S., Benassai, S., Castellano, E., Fattori, I., Innocenti, M., Migliori, A., and Traversi, R.: Atmosphere-snow interaction by a comparison between aerosol and uppermost snowlayers composition at Dome C, East Antarctica, Ann. Glaciol., 39, 53-61, 2004.

Van Allen, R., Liu, X., and Murcray, F. K.: Seasonal variation of atmospheric nitric acid over the South Pole in 1992, Geophys. Res. Lett., 22(1), 49-52, 1995.

van den Ende, D., Stolte, S., Cross, J. B., Kwei, G. H., and Valentini, J. J.: Evidence for two different transition states in the reaction of $\mathrm{NO}+\mathrm{O}_{3} \rightarrow \mathrm{NO}_{2}+\mathrm{O}_{2}$, J. Chem. Phys., 77(4), 2206-2208, 1982.

van den Ende, D. and Stolte, S.: The influence of the orientation of the NO molecule upon the chemiluminescent reaction $\mathrm{NO}+\mathrm{O}_{3}$ $\rightarrow \mathrm{NO}_{2} *+\mathrm{O}_{2}$, Chem. Phys., 89, 121-129, 1984.

von Glasow, R., von Kuhlmann, R., Lawrence, M. G., Platt, U., and Crutzen, P. J.: Impact of reactive bromine chemistry in the troposphere, Atmos. Chem. Phys., 4, 2481-2497, 2004, http://www.atmos-chem-phys.net/4/2481/2004/.

von Glasow, R. and Crutzen, P. J.: Model study of multiphase DMS oxidation with a focus on halogens, Atmos. Chem. Phys., 4, 589608, 2004, http://www.atmos-chem-phys.net/4/589/2004/.

von Savigny, C., Ulasi, E. P., Eichmann, K. U., Bovensmann, H., and Burrows, J. P.: Detection and mapping of polar stratospheric clouds using limb scattering observations, Atmos. Chem. Phys., 5, 3071-3079, 2005, http://www.atmos-chem-phys.net/5/3071/2005/.

Wada, E., Shibata, R., and Torii, T.: N-15 abundance in Antarctica - Origin of soil-nitrogen and ecological implications, Nature, 292(5821), 327-329, 1981.

Wagenbach, D., Legrand, M., Fischer, H., Pichlmayer, F., and Wolff, E. W.: Atmospheric near-surface nitrate at coastal Antarctic sites, J. Geophys. Res., 103(D9), 11 007-11 020, 1998.
Wagnon, P., Delmas, R. J., and Legrand, M.: Loss of volatile acid species from the upper firn layers at Vostok, Antarctica, J. Geophys. Res., 104(D3), 3423-3431, 1999.

Warneck, P.: Chemistry of the natural atmosphere, 927 pp., Academic Press, San Diego, 2000.

Warneck, P.: Chemistry of the natural atmosphere, 757 pp., Academic Press, London, 1988.

Weller, R., Jones, A. E., Wille, A., Jacobi, H. W., McIntyre, H. P., Sturges, W. T., Huke, M., and Wagenbach, D.: Seasonality of reactive nitrogen oxides $\left(\mathrm{NO}_{\mathrm{y}}\right)$ at Neumayer Station, Antarctica, J. Geophys. Res., 107(D23), 4673, doi:4610.1029/2002JD002495, 2002.

Weston, R. E.: When is an isotope effect non-mass dependent?, J. Nucl. Sci. Technol., 43(4), 295-299, 2006.

Wolff, E., Legrand, M., and Wagenbach, D.: Coastal Antarctic aerosol and snowfall chemistry, J. Geophys. Res., 103(D), 10927-10 934, 1998.

Wolff, E.: Nitrate in polar ice, in: Ice core studies of global biogeochemical cycles, edited by: Delmas, R., pp. 195-224, SpringerVerlag, New York, 1995.

Wolff, E. W., Jones, A. E., Martin, T. J., and Grenfell, T. C.: Modelling photochemical $\mathrm{NO}_{\mathrm{x}}$ production and nitrate loss in the upper snowpack of Antarctica, Geophys. Res. Lett., 29(20), 1944 doi:1910.1029/2002GL015823, 2002.

Young, E., Galy, A., and Nagahara, H.: Kinetic and equilibrium mass-dependent isotope fractionation laws in nature and their geochemical and cosmochemical significance, Geochim. Cosmochim. Acta, 66(6), 1095-1104, 2002.

Zahn, A., Franz, P., Bechtel, C., Grooß, J.-U., and Röckmann, T.: Modelling the budget of middle atmospheric water vapour isotopes, Atmos. Chem. Phys., 6, 2073-2090, 2006, http://www.atmos-chem-phys.net/6/2073/2006/.

Zeller, E. J. and Parker, B. C.: Nitrate Ion in Antarctic Firn as a Marker for Solar-Activity, Geophys. Res. Lett., 8(8), 895-898, 1981.

Zhang, H., Wennberg, P. O., Wu, V. H., and Blake, G. A.: Fractionation of (NNO)-N-14-N-15-O-16 and (NNO)-N-15-N-14-O-16 during photolysis at $213 \mathrm{~nm}$, Geophys. Res. Lett., 27(16), 24812484, 2000.

Zhang, J. S., Miau, T. T., and Lee, Y. T.: Crossed molecular beam study of the reaction $\mathrm{Br}+\mathrm{O}_{3}$, J. Phys. Chem. A, 101(37), 69226930, 1997. 